\title{
Trade, Technological Change, and Wage Inequality: The Case of Mexico
}

\author{
Andrea Waddle* \\ University of Richmond \\ awaddle@ richmond.edu
}

February 2017

\begin{abstract}
In the decade following the Mexico-U.S. trade integration, the manufacturing skill premium rose by almost 60 percent in Mexico and by only 12 percent in the U.S. Standard trade theory predicts that when countries with different levels of skilled labor integrate, the skill premium should fall - not rise - in the skill-scarce country. In this paper, I reconcile theory and data by building a model in which intermediate goods are produced using rented technology. After integration, producers in Mexico begin to rent technologies from the United States, which are more advanced and, hence, more skill-intensive. This has two effects: The skill premium in Mexico rises due to adoption of the more advanced technology and the skill premium in the U.S. rises due to increased investment in this technology, which is driven by the increased marginal return on technology arising from its adoption in Mexico. The mechanism is supported by industry-level evidence: Mexican industries which are integrated into the U.S. supply chain have higher skill premia than their non-integrated counterparts. The calibrated model can account for about two-thirds of the increase in the skill premium in each country.
\end{abstract}

${ }^{*}$ I am indebted to Tim Kehoe and Ellen McGrattan for valuable advice and guidance. I am grateful for comments and suggestions from Ariel Burstein and two annonymous referees. I would also like to thank Cristina Arellano, Alessandro Dovis, Larry Jones, Fabrizio Perri, Joe Steinberg, David Wiczer, and the participants of the Trade workshop at the University of Minnesota for their useful comments and discussions. I acknowledge the financial support of the University of Minnesota Doctoral Dissertation Fellowship. The usual disclaimers apply. 


\section{Introduction}

Standard trade theory has stark predictions for how factor prices should respond to trade integration between a skill-scarce and a skill-abundant country. In particular, models that are based on the Heckscher-Ohlin (henceforth $\mathrm{H}-\mathrm{O}$ ) theory predict that the ratio of wages paid to skilled versus unskilled workers (the skill premium) should rise in the skill-abundant country and fall in the skill-scarce country when the two countries open to trade with one another. A puzzle that has arisen in the context of this prediction is that when integrating with the world economy, many skill-scarce countries instead experience rising skill premia. Mexico is the canonical example of a country whose skill premium not only rose, but rose by much more than that of its more-developed counterpart, the United States, during the period in which Mexico opened its borders to trade with the United States. These observations have led many researchers to conclude that skill-biased technological change (SBTC), not increased openness to trade, has driven changes in developing economies' skill premia.

In this paper, I argue that trade liberalization, by stimulating investment in skill-biased technologies and facilitating cross-border adoption of these technologies, plays an important role in explaining the aforementioned facts. I modify a standard trade model to include trade in technology, which occurs through the integration of supply chains across borders. I use the case of the Mexican trade liberalization and integration into the supply chain of American companies to explore the impact that technological transfer, which takes place as a part of this integration, has upon the wages of workers in Mexico and the United States. I calibrate the model using surveys of the Mexican and the U.S. manufacturing sectors and I find that a reduction in barriers to trade in goods and technology can account for about two-thirds of the observed increase in the skill premium in both Mexico and the United States.

To support my quantitative analysis, I provide empirical evidence at the industry-level that indicates that Mexican industries which trade more with the United States have higher skill premia on average and have greater increases in their skill premia in the late 1980s than their non-trading counterparts. This analysis suggests that trade connections are an important determinant of skill premia and that supply chains could be channels through which technology is transferred. While I do not have direct information about connections between the Mexican plants and the firms that they are supplying in the United States, I show that trade between the two countries rose dramatically over the course of the late 1980s and early 1990s. Moreover, intra-industry trade 
began to dominate Mexican-U.S. trade during the mid-1980s and has continued to do so ever since. I show that the use of intermediate imports is an important predictor of the skill premium, indicating that supply chain relationships play an important role in determining the skill premium in a given industry.

In order to assess the quantitative importance of supply chains on the skill premium, I adapt a standard trade model to allow for trade liberalization to increase both trade in goods and trade in ideas. I model "ideas" as technology capital, similar to the model in McGrattan and Prescott (2009), but I allow for technology capital to be rented from final goods producers, who own and invest in the stock of technology capital, to intermediate goods producers, who use it. I model trade liberalization as a reduction both in tariffs on goods and in taxes on flows of royalties. I discipline my exercise using manufacturing data from Mexico and the United States.

My model differs from those in the existing literature by incorporating two key ingredients. First, I allow for skill-biased technology to be endogenously accumulated by permitting firms to invest in a stock of technology that is assumed to be skill-augmenting. I consider final goods producers who own and invest in technology capital. Intermediate suppliers rent this technology capital in order to produce an intermediate product that will be a component of the final good. Consider for the moment a two country world in which both countries are in autarky. When the countries open to trade, the final goods producer does not need to open a plant in the foreign country in order to use his technology capital there. Instead, he can rent his technology to an intermediate goods producer that is already operating in the foreign country. This, in turn, increases the marginal product of a unit of technology capital since now it can be used by additional intermediate goods producers. It is key that technology capital is non-rivalrous so that using it in multiple locations actually increases its marginal productivity. Opening to trade, therefore, increases the return to technology capital, as in McGrattan and Prescott (2009). Firms respond to these increased returns to their technology capital by investing more. I refer to this as the "investment channel," and it is the main channel that drives the increase in the skill premium seen in the United States. This is consistent with recent empirical work in Goel (2012) which provides evidence that firms in the United States respond to increased trade opportunities by increasing spending on innovation. Moreover, it is consistent with extant literature which has found that the rise in the skill premium in the United States is driven primarily by technological change. Note that this does not mean that opening to trade plays no role in increasing the skill premium, but rather, that its role manifests as an increase in technology, driven by increased returns to investment in that technology.

Second, I allow technology capital to be rented across borders. I provide industry-level evidence that royalties paid as a percentage of output in Mexico co-varies positively with the skillpremium, meaning that industries that use more rented technologies are those that have larger skill 
premia; I take this as evidence of transfer of technology. Allowing for technology to be transferred through rental is the key to having the skill premium rise in both countries because it causes the skill premium to rise in the United States via the investment channel, as discussed above, and it causes the skill premium to rise in Mexico by what I will call the "adoption channel." The "adoption channel" arises when intermediate goods producing firms in one country begin to produce for the supply chain of the final goods producer in the other and, therefore, adopt the technology of the final goods producer in the foreign country. In the model, intermediate goods producers in Mexico choose to adopt U.S. technology and supply U.S. final goods producers much more than vice versa. This is because, in the initial steady state, U.S. technology is much more productive than Mexican technology. Therefore, the adoption channel is the dominant force driving the increase in the skill premium in Mexico.

In my calibrated model, I find that moving from an autarkic steady state to a free trade steady state induces a skill premium increase of 39 percent in Mexico and 8 percent in the United States. This accounts for about two-thirds of the observed rise in both the Mexican skill premium and in the skill premium in the United States.

The adoption channel is key to obtaining these results. If I shut down the firm's ability to trade technology, under my baseline calibration, results show the standard Stolper-Samuelson effect, with Mexico's skill premium declining and that of the United States increasing. The StolperSamuelson effect is offset, in part, by the investment channel. I include two sectors in the model - one that is skilled-labor intensive and one that is unskilled-labor intensive - in order to allow for this type of effect, but both sectors use skill-augmenting technology capital. Opening to trade allows countries to specialize in the sector in which they have a comparative advantage, which in turn increases the return to the factors of production, thus inducing firms to invest more in the skillaugmenting technology in that sector. This raises the return to skilled workers for all countries, reducing the decline in the skill premium in Mexico. The big gain in the Mexican skill premium comes, however, through the rental of advanced technology from the United States. In the model, there is an initial jump in the skill premium in Mexico as U.S. technology becomes available to Mexican firms. This results from the sudden inflow of this technology into Mexico, which occurs when the distortion on royalties is reduced and the price of renting the U.S. technology falls as a consequence.

My quantitative results are disciplined by manufacturing data for the United States and Mexico. Because my interest lies primarily in how the skill premium changed in the two countries, I target the level of the skill premium in the initial period. I use aggregated industry data from Mexico on royalty payments to pin down the parameter that governs the importance of technology capital in production. In particular, I match royalty payments as a percentage of payroll payments in 
the period before trade liberalization. I use 1985 as the "pre-reform" period; as I will document below, the majority of Mexican trade reforms began in 1986. I also set the relative productivity of the manufacturing sectors in the two countries and the relative supply of skilled workers in each country in 1985 to match the data. In order to see how trade reform impacts the skill premium, I then conduct an experiment where I lower tariffs on goods and taxes on royalties. While I am able to directly observe the reduction in tariffs that occurred in the data, I am not able to observe directly a measure of the distortions on royalty payments. This is because things such as the protection of intellectual property would have a strong impact on a firm's willingness to rent proprietary information to other firms and these protections changed substantially over the period of interest. Therefore, I conduct the extreme experiment whereby I set initial distortions sufficiently high that there is no trade in technology and then I lower these distortions to zero. I then analyze how the results would change if I were to set the distortionary tax on royalties to some intermediate level. I find that opening to trade in both technology and goods increases the skill premium in both countries. I am able to decompose this change in the skill premium and attribute most of the rise in the skill premium in Mexico to the adoption channel and almost all of the rise in the United States to the investment channel.

\section{Contribution to Related Literature}

There is a large body of literature dealing with the rise of the skill premium in the United States, and a somewhat smaller literature on the rise of the skill premium in Mexico. Studies such as Feenstra and Hanson (1996), Feenstra and Hanson (1997), and Grossman and Rossi-Hansberg (2008) have shown that increasing imports of intermediate goods from less-developed countries can increase skill premia in advanced economies. For a useful summary of articles that have explored the behavior of the skill premium of developing countries as they open to trade, see Goldberg and Pavcnik (2007).

The papers that are most closely related to my own are Feenstra and Hanson's 1996 empirical and theoretical work on the importance of foreign direct investment (FDI) in Mexico and Bustos' 2011 exploration of skill upgrading in Argentina following their accession to MERCOSUR. Empirically, the Feenstra and Hanson show that regions with a higher proportion of inward FDI from the United States have greater increases in the relative demand for skilled labor. Furthermore, they build a theoretical model which rationalizes this prediction; capital is complementary with skilled labor, and as capital flows from the United States to Mexico via foreign direct investment, demand for skilled labor rises in Mexico. The Mexican subsidiary of the multinational in Mexico produces a less-skilled intermediate which is then substituted for less-skilled workers in the United States. 
Thus, the relative demand for unskilled workers falls in the United States as well. I see my paper as a complement to their work. At the aggregate level, flows of foreign direct investment between Mexico and the United States did not rise substantially until the mid-1990s. Moreover, the majority of growth in both maquiladora ${ }^{1}$ establishments and employment came after the North American Free Trade Agreement (NAFTA) (GAO, 2005), and, as such, post-dates the observed growth in the skill premium in Mexico. I focus on the transfer of technology through non-ownership channels precisely because trade increases substantially before NAFTA but direct investment does not. I provide evidence that supply chains are an important channel through which technology is transferred. The mechanism proposed in their paper is also similar to what I propose. However, in their setup, the investment channel that I describe is not present. This is because the type of capital they consider is physical capital, which can be only used in one location at a time. I, instead, consider technology capital which can be used in multiple locations at once. Therefore, once a firm has more than one location in which to use its technology, it has an increased incentive to invest in it. This is the primary driver of the increase of the skill premium in the United States in my model, whereas in the Feenstra and Hanson model, the increase in the skill premium in the United States is primarily driven by Stolper-Samuelson effects.

In Bustos (2011), the author analyzes firm-level panel data covering the period of Argentinian trade liberalization with Brazil and documents that there is a steep increase in the demand for skill in Argentina following said liberalization, which is driven primarily by skill-upgrading within firms. She further finds that exporters engage in upgrading activities more quickly than nonexporters and that this skill-upgrading is accompanied by investments in new technologies. She then presents a modified Meltiz model that can rationalize these observations through a mechanism that is similar but distinct from the one that I consider here. In Bustos' model, there is a fixed cost to exporting, as well as a fixed cost to operating a technology that is both more productive and more skill intensive than the alternative. The fixed cost set-up causes there to be a cut-off level of productivity above which firms will choose to both export and use the better, more skill intensive technology. Thus, the main driver of skill-grading in this model operates through the standard Melitz logic: a reduction in tariffs causes the per-unit profit of exported goods to increase, thus reducing the cut-off level of productivity needed to export and upgrade to the better technology. Therefore, more firms export and operate this advanced technology after the trade liberalization. There is a similar observation as a result of trade liberalization in my model; however, my model differs both in terms of the key assumption and the implications for the impact of a trade liberalization. First, the key assumption in my model is that there is a stock of technology, which grows through investments made by the final goods producer and is rented to the intermediate goods

\footnotetext{
${ }^{1}$ manufacturing plants in the free trade zone
} 
producer that will produce a part for the owner of that particular technology. The producer of an intermediate variety, i.e. a part used to produce the final good, is allowed to produce for the final goods producer in each country but must operate the technology from the country of the final goods producer in order to do so. A trade liberalization impacts the intermediate goods producer by making the part that they produce less expensive for the foreign final goods producer, thus inducing them to produce more parts for the foreign final goods producer. Because they are forced to use the technology of the foreign goods producer in order to produce a part for this supply chain, the domestic firm will become more skill-intensive if the foreign technology is skill augmenting and there is a larger stock of technology capital in the foreign country. This, in turn, will cause the domestic skill premium to increase. Moreover, because the technology capital that I consider is non-rivalrous, the fact that the foreign final goods producer's technology is now being used more intensively means that there is a greater return to investing in that technology, thus causing them to increase investment and therefore the stock of this skill-augmenting technology. The adoption of foreign technologies thus induces an increase in skill intensity in both countries. The asymmetry of the two countries is one of the primary drivers of the greater increase in the skill premium in the less skill-abundant country; the stock of technology capital in the skill-abundant country is much larger and, therefore, when the skill-scarce country begins to produce for the supply chain of the skill-abundant one, the skill premium in the skill-scarce country will increase dramatically. This asymmetric response will not occur in the framework proposed by Bustos and so, while her model can generate increasing skill premia in both countries, it is ill-equipped to explain why Mexico's skill premium increased by so much more than that of the United States.

I also contribute to the emerging literature on the interaction between trade, technology, and inequality. My work completments papers such as Acemoglu (2009), Acemoglu, Gancia, and Zilibotti (2012), and Burstein and Vogel (2010), which all address the idea that trade and technological innovation are linked. Acemoglu (2009) and Acemoglu, Gancia, and Zilibotti (2012) both build theoretical models in which globalization, in the form of trade or offshoring, can induce skill-biased technical change through increasing the price of skill-intensive goods and, hence, the profitability of investing in the technologies that are needed in order to produce these goods. The logic which supports the increase in skill-biased technology in these papers is the same as the one that I present here: trade makes it such that investing in these technologies is more profitable. Moreover, the driver of the increasing skill premia in less developed countries in these models is the same as the one considered here: technologies that are more skill-biased are adopted by the less developed countries. My paper adds to these two by proposing a mechanism by which these technologies may be adopted by firm in the less developed countries and, in doing so, provides a way to understand why skill premia in less developed countries do not follow identical patterns following trade liberalizations with advanced countries. Burstein and Vogel (2010) build a quan- 
titative multi-country model in which trade induces reallocation within economies towards more productive and skill-intensive firms. This model is able to generate increasing skill premia in all countries following a reduction in tariffs. My model differs from the one considered by Burstein and Vogel in that a firm's productivity is determined by their stock of technology capital used for production in my model while it is the result of an exogenous draw in theirs. Both models feature endogenous increases in productivity, as in their model, firms with lower productivity draws are forced to shut down following a trade liberalization due to increased foreign competition. However, in my model, final goods producers must choose to invest in this technology in order for its stock to increase. This choice lends itself to consider the case of vertically integrated supply chains, while the set up in Burstein and Vogel (2010) does not lend itself as readily to considering how parts producers interact with the final goods producer for which they are part of the supply chain.

This paper is also related to the literature that has explored the impact of globalization on Mexican labor markets. A number of studies (for example, see Esquivel and Rodriguez-Lopez, 2003; Harrison and Hanson, 1999; and Robertson, 2004) explore this question using the StolperSamuelson theorem as their basis, and find the correlation between changes in output prices and wages at the industry level to be very low. The conclusion from this strand of literature was that skill-biased technological change, and not trade, was responsible for the observed increase in the skill premium. Verhoogen (2008) explores both overall increase in inequality and the betweenplant inequality in Mexico and hypothesizes that exporting opportunities increase wage dispersion across plants due to quality upgrading. Riano (2009) builds a model in which SBTC is embodied in capital equipment and measures the effect of increasing imports of capital equipment upon the skill premium in Mexico. The idea in his paper is similar to what I model here, but importantly, the capital that is traded in my model is technology capital or "ideas." The non-rivalrous nature of technology capital creates an environment such that even as the capital begins to be used in Mexico, firms in the United States have an incentive to invest more in it. In fact, it is because the ideas are being used in an additional location that their marginal product increases.

Also related to this paper is the literature on the skill premia in developing countries. Ripoll (2005) builds a model in which the skill premium in the developing country responds non-monotonically to trade liberalization and depends heavily on the initial conditions in the economy. Trefler and Zhu (2005) show that those countries with the largest increase in skill premia following a trade liberalization are those which export relatively more skill-intensive goods, and they build a model akin to Feenstra and Hanson (1996), but allowing the "South" to catch up to the technology of the "North" instead of receiving FDI flows. They do not propose a mechanism for how this catchup occurs. Burstein, Cravino, and Vogel (2013) and Parro (2013) each propose capital-embodied 
technology as an avenue by which skill-biased technological change crosses borders. I contribute to this literature by proposing an alternative way that this technology is accumulated and then transmitted from one country to the next, and I provide evidence of my hypothesis.

The paper is organized as follows: In Section 2, I provide brief background information on the trade liberalization experience in Mexico in the late 1980s; in Section 3, I provide evidence for the importance of trade linkages for the skill premium: Section 4 contains my model and its theoretical analysis; Section 6 contains my calibration and results; and Section 7 concludes.

\section{Background: Trade Reform in Mexico}

This section briefly describes the liberalization policies that were implemented in Mexico in the mid-1980s and examines the special case of one auto plant within Mexico as an example of how trade induces technology transfer.

\subsection{Mexico's Trade Liberalization}

During the 1950s, Mexico began to pursue a set of policies based on the theory of import substitution. As such, during this time, Mexico became one of the most closed economies in the world, with more than 90 percent of its domestic production subject to import licenses by 1985 . Import licenses are commonly viewed as the main source of restricted trade flows (Kehoe, 1995, TenKate 1992), though, in practice, Mexico utilized three instruments to restrict these flows: (i) ad-velorum tariffs, (ii) official minimum prices for custom valuation, and (iii) quantitative restrictions such as quotas and the aforementioned import licenses. As a result of the balance of payments crisis in 1982, the Mexican government decided to pursue a large-scale liberalization of the Mexican economy, including a massive trade liberalization (apertura), in order to restart economic growth.

In 1985, the Mexican government undertook a number of structural reforms, including reducing the import license coverage from 92 percent to 47 percent between June and December of that year. Many of these reforms were requirements of the debt restructuring agreement that Mexico entered with its international creditors in the wake of the debt crisis in the early 1980s. The government continued to phase out import licenses over the course of the decade, with the coverage falling to 23 percent in 1988 and 19 percent in 1989. Most of the remaining import licenses covered agricultural and petroleum refining products. Over the same period, ad-velorum tariffs fell as well. In 1985, the maximum tariff was 100 percent; only a year later, in 1986, it was reduced to 50 percent. By 1987, the maximum tariff was 20 percent and the production-weighted average tariff 
was 11 percent (Esquivel and Tornell, 1995).

Mexico also entered into trade negotiations with the United States in 1987, which culminated in a four-part understanding known as the "Framework of Principles and Procedures for Consultation Regarding Trade and Investment Relations" or the "Bilateral Accord." This Accord was the firstever formal bilateral agreement governing commercial relations between the two countries, and it included a statement of principles, a mechanism for consultations, an agreement on data exchange, and an Immediate Action Agenda. The Immediate Action Agenda was the start of negotiations on a number of matters, including technology transfer. In particular, Mexico was interested in obtaining help from developed nations to develop its intellectual property rights protection laws so that technological transfer from companies in the United States would be more forthcoming. Mexico argued that access to new technologies was of utmost importance and was a necessary component to any improved trade arrangement between the two countries (DuMars, 1991). The recognition of intellectual property rights was an important step to allowing for transfer of technology between the two countries.

During this period, the government also began to loosen its restrictions on foreign ownership; however, the process was slower to change than other policies, and significant restrictions remained in place for the next decade. In particular, foreign companies were not allowed to acquire existing Mexican firms without submitting to a lengthy approval process. Establishing a new foreign-owned business was somewhat easier, but only if the business fit certain criteria, which included a requirement that the business have at least a non-negative net export balance over the first three years of its existence. Maquiladora firms were exceptions to these rules, but the process for obtaining a license establishing a firm as a maquiladora was viewed as relatively cumbersome until the process was reformed in December of 1989. However, to the extent that foreign ownership was allowed, this also served as a channel for technological transfer across the two countries.

In 1992, the Mexican government signed an agreement to enter into the North American Free Trade Agreement (NAFTA) with the United States and Canada on January 1, 1994. As part of NAFTA, all remaining tariffs on goods traded between the two countries would be phased out over the next decade. Moreover, the three countries agreed to abide by the intellectual property rights laws of the United States. Contrary to commonly held beliefs, the trade liberalization that took place during the 1980s was more substantial and impactful than NAFTA. By the time that NAFTA was signed, approximately $95 \%$ all of imports into Mexico from the U.S. were subject to import tariffs of $20 \%$ or less and $80 \%$ of imports into the U.S. from Mexico were subject to tariffs of $5 \%$ or less. This stands in stark contrast to the $100 \%$ import tariffs that were common in 1985. 


\subsection{Trade and Technology Transfer: A Case Study of an Auto Plant}

As an example of the transfer of technology capital, I now turn to a case study of one company's vertical integration of its supply chain, including a plant in Northern Mexico, conducted by Shaiken and Herzenberg (1987). This particular plant was partially owned by an undisclosed American auto manufacturer to make engines and engine parts for cars that would be exported, in keeping with Mexican regulations that required that a large proportion of output from foreign owned plants be produced for export. The case study consists of interviews with both production and nonproduction workers and it directly compares the Mexican plant with its U.S. counterpart, in terms of production techniques, technology used, management practices, and quality and quantity of output. The Mexican plant was a brand new facility, which utilized some of the most advanced production technologies available at the time of its construction and it was built to compete wtih the most successful engine plants in the world.

The study finds that the Mexican plant was able to achieve efficiency that was comparable to that of the U.S. plant, due in large part to its utilitzation of technology capital that was the same across the two locations. The company invested significant resources in training the workers to operate state of the art machinery and to manage according to the company's best management practices. The case study details how supply chains served as a way to transfer blueprints for the production of parts, technology embedded in intermediate parts and in machines, best practices for efficient production, and organizational capital, such as worker training programs. These types of technology capital impacted production and non-production workers differentially. One place that this is evident is in the worker trainign programs implemented by the company. Non-production workers, such as technicians, had to require many skills that were not part of their previous skill-set. In order to do so, there were task certification programs, in-plant and on-the-job training programs and apprenticeships, and even trips to the tool suppliers in the United States, all to ensure that the technicians understood how to maintain the plant. Production workers also received training, but to a lesser extent.

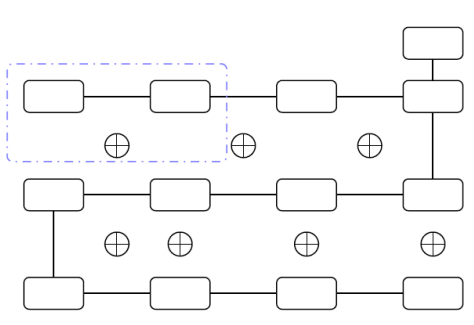

(a) Standard

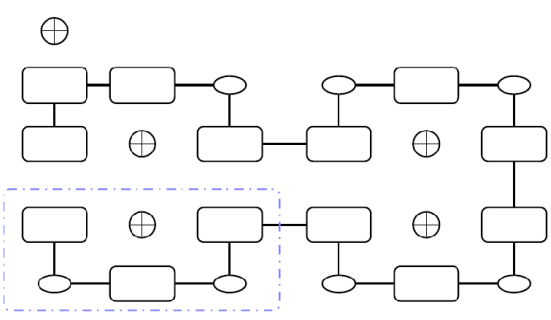

(b) Modified

Figure 1: Production Line Layouts 
Another example of the transfer of technology capital is the modification of the production line layout. Figure (1a) shows the standard layout for a production line, where each circle with a cross in it represents a worker and each rounded solid box is a machine that needs to be operated. Figure (1b) displays the new layout used by the company. As can be seen by examining the areas enclosed with the dotted blue lines, in the standard layout each worker is in charge of two machines, whereas in the new layout, each worker is in charge of three machines. This changes the mix of workers necessary in the plant; because now each production worker is operating more machines, all else equal, fewer production workers are required. However, because this may lead to more breakdowns on the line, there are more technicians (non-production workers) required. This technology augments the skilled non-production workers and substitutes for the unskilled production workers. This case study serves to highlight the role of integrated supply chains in transfering skill-augmenting technology capital across borders.

Logially, does it make more sense for this to be in the next section? it is evidence of the impact of trade on the skill premium.

\section{Evidence on Skill Premia and Trade}

\subsection{Data Description}

Data for Mexico's manufacturing sector comes from INEGI (Instituto Nacional de Estadística y Geografía), Mexico's national statistics bureau. I gather aggregate skill premium data from the EIA (Encuesta Industrial Anual), which is an annual survey of manufacturers which covers about 80 percent of the manufacturing sector. Aggregate data from 1980 through 2004 is publicly available on INEGI's website. I gather data on production and non-production employees and payments to these two groups and construct the skill premium as the ratio of non-production wages to production wages, as is standard in the literature. Industry-level data is available by request for years 1984 through 1994, and plant-level data is available from 1984 through 1990. The plantlevel data includes information on imports and exports by plant for the years 1986 to 1990. This information was gathered in a special survey conducted by the World Bank. For a more detailed description of the plant-level data, see Tybout and Westbrook (1995).

Data for the U.S. manufacturing sector is obtained from the NBER-CES Manufacturing Productivity Database (Bartelsman and Gray, 1996). This data is available from 1959 through 2010. Again, the database provides information on production and non-production employees, as well as payments to each group. I then construct the skill premium as the ratio of non-production wages 
to production wages. I compare the manufacturing skill premium to the ratio of college to noncollege wages, which I compute using the Current Population Survey (CPS). I obtain the March CPS from Integrated Public Use Microdata Series, Current Population Survey (IPUMS CPS) at the Minnesota Population Center. I then compute the ratio of wages for working age people with some college and above to those with no college, and call this the "college premium."

Aggregate trade data for Mexico is obtained from the World Bank World Development Indicators Database (WDI). I gather information on imports, exports, and gross domestic product, as well as subsets of the trade data. In particular, I examine merchandise trade, merchandise trade with advanced economies, and trade in manufactures. Each variable gathered is expressed in millions of U.S. dollars. I then express each trade variable as a percentage of gross value added in manufacturing. I cross reference these trade data with data from the NBER's U.S. imports and exports database, 1972-1994, (Feenstra 1996, 1997) to verify that the majority of the increase in Mexico's trade was with the United States.

Information on intermediate imports is gathered from the Organization for Economic Cooperation and Development's (OECD) Structural Analysis (STAN) Database. This database provides total bilateral imports and exports, as well as intermediate bilateral imports and exports, between the U.S. and Mexico for years 1990 through 2010 for broad industries. I match this data (19901994) with the industry-level data for Mexican manufacturing for the same broad sectors.

\subsection{Skill Premia in Mexico and the United States}

In what follows, I will use the term "skill premium" to mean the ratio of the wages of nonproduction workers to the wages of production workers, as is typical in the literature that examines the skill premium in developing countries. Amiti and Cameron (2011) use data that includes educational attainment and production/non-production status of workers in Indonesian manufacturing for several years and they show that the production/non-production breakdown is a good proxy for skill or educational attainment. Therefore, I will focus my analysis on this measure of the skill premium. In Mexico, the skill premium was stable with non-production wages being about twice as high as production wages during the late 1970s and early 1980s, but began to rise around 1986. It grew for the next decade and peaked with non-production wages being about 3.1 times higher than production wages in 1996. This can be seen in Figure 2a. The U.S. experienced similar timing in the rise of the same variable. Note that the college premium, measured as the ratio of college to non-college wages, began to rise earlier in the 1980s. The college premium is the measure which is frequently the concentration of papers dealing only with the United States, but I will concentrate on comparable measures of the skill premium in this paper. As can be seen in Figure $2 \mathrm{a}$, the 
manufacturing skill premium in the United States also began to rise in the mid-1980s.

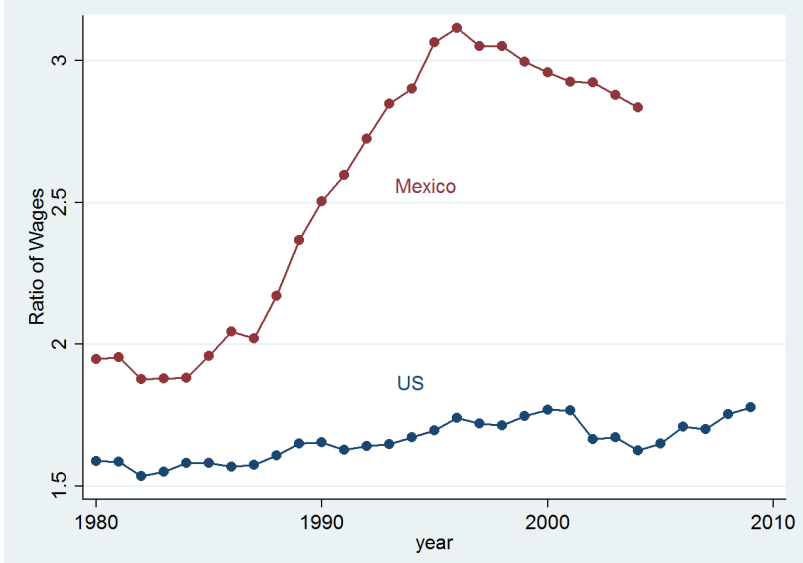

(a) Levels

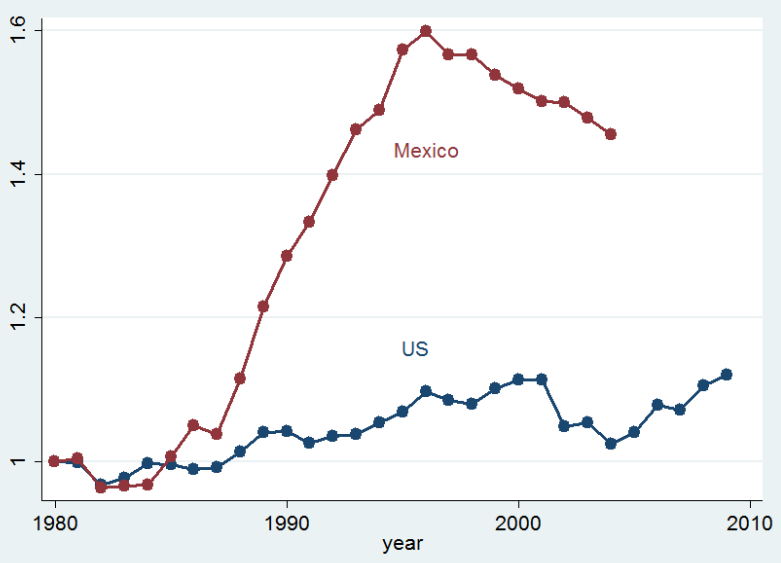

(b) Relative to 1980

Figure 2: Skill Premia in U.S. and Mexico

Figure 2a also shows that the skill premium in Mexico was substantially higher than that in the United States and rose by much more over the period of interest. Figure $2 b$ shows that the timing of the increases in the two skill premia largely coincided. It also highlights that the increase in Mexico was substantially bigger than that in the United States. In particular, over the course of the decade from 1986 to 1996, the skill premium in Mexico rose by about 60\%, while the skill premium in the United States rose by about 10 to $15 \% .^{2}$ The timing and magnitude of the increase in the college premium is similar to that of the manufacturing skill premium, though the manufacturing skill premium does not exhibit the same drop as the college premium in the 1970s.

\footnotetext{
${ }^{2}$ Again, the measure of the skill premium is different from the one that is often cited in the literature concerning the rise of inequality in the United States.
} 

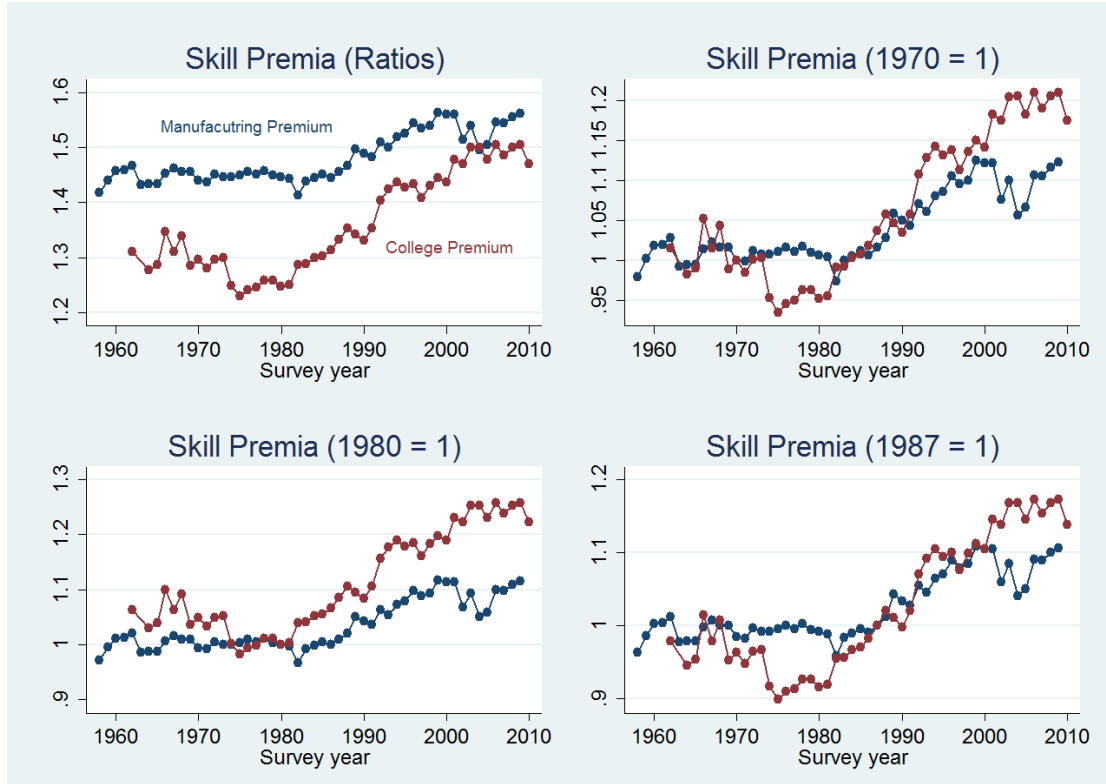

Figure 3: Manufacturing Skill Premium and College Premium in U.S.

Figure 3 shows how the college premium and the manufacturing skill premium move together in the United States. I measure the college premium as the ratio of wages of those with at least one year of college to those with no college education. As is well known, the college premium fell over the course of the 1970s as the supply of college-educated workers grew. During this period, the manufacturing skill premium remained flat. If you disregard the education premium drop that occurred over the 1970s, the panels of figure 3 show that the timing of the rise in the education and manufacturing skill premium largely coincide. In particular, when I normalize the college premium to 1 in 1970 (as in the second panel of the figure), it can be seen that the two series begin to rise above their long-run trend at about the same time, and by 2000 they had risen by roughly the same amount. The rise in the skill and education premia from 1985 to 2000 is roughly 12 percent. Therefore, the skill premium in Mexico rose by about four times as much as its American counterpart from 1986 to 2000.

\subsection{Increase of Manufacturing Trade}

In this section, I show that the increase in the skill premium in Mexico largely coincides with an increase in manufacturing trade. Figure 4a shows Mexican imports and exports of manufactured goods as a percentage of total value added in manufacturing. We can see that trade in manufactured goods began to rise in the mid-1980s and continued to rise through the early 2000s. This timing is consistent with the growth of the skill premium in Mexican manufacturing documented above. 
Notably, the growth in exports and imports begins well before the implementation of the North American Free Trade Agreement (NAFTA).

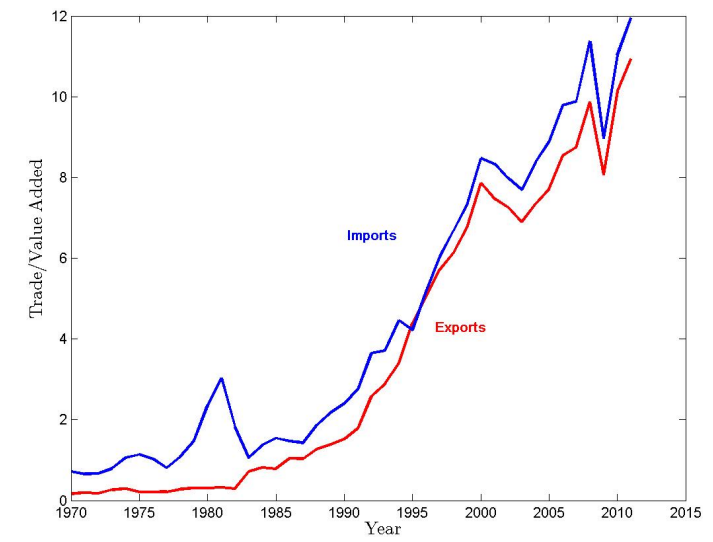

(a) Manufacturing Trade

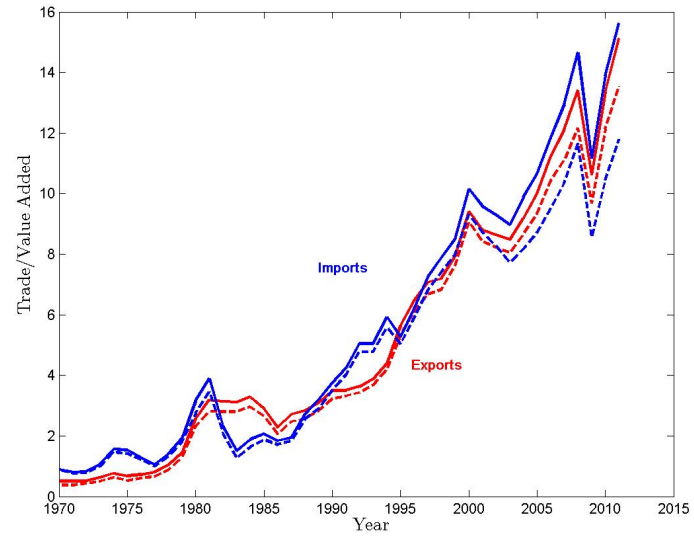

(b) Merchandise Trade

Figure 4: Mexican Manufacturing Trade

Figure $4 \mathrm{~b}$ documents the percent of merchandise trade that was taking place with high-income countries. The solid lines represent the total amount of merchandise imports (blue) and exports (red) as a percentage of value added and the dotted lines show the merchandise trade occurring with high-income OECD countries. I use this measure because I do not have an accurate measure of trade in manufactured goods with high-income countries, but I do have a measure of trade in merchandise goods with high-income countries. Merchandise trade consists almost entirely of trade in manufactured products, especially in the later periods. I use aggregated data from the NBER's import and export database to verify that this trade is predominantly with the United States. This figure is meant to illustrate that Mexico's trade liberalization in the 1980s predominantly increased its trade with the United States, a more-developed country. This means that according to a standard $\mathrm{H}-\mathrm{O}$ model, we should expect to see a falling skill premium in Mexico. If Mexico had opened to more skill-scarce countries during this period, one might anticipate that its skill premium would rise, but since it was increasing trade predominantly with the United States, the opposite should be true.

\subsection{Evidence that Supply Chains Matter}

In order to explore how trade integration impacts the skill premium, I match the industry-level data on manufacturing wages and employment to trade data from the OECD STAN database. I have information on intermediate imports, intermediate exports, total imports, and total exports for 20 
industries from 1990 to 1994 . I match this information to the information on the skill premium for the same broad industries. I then examine the relationship between imports of intermediates as a fraction of output, exports as a fraction of output, royalty payments, and the skill premia by industry. In order to do this, I first estimate the following equation, where $i$ indexes the industry and $t$ indexes the year:

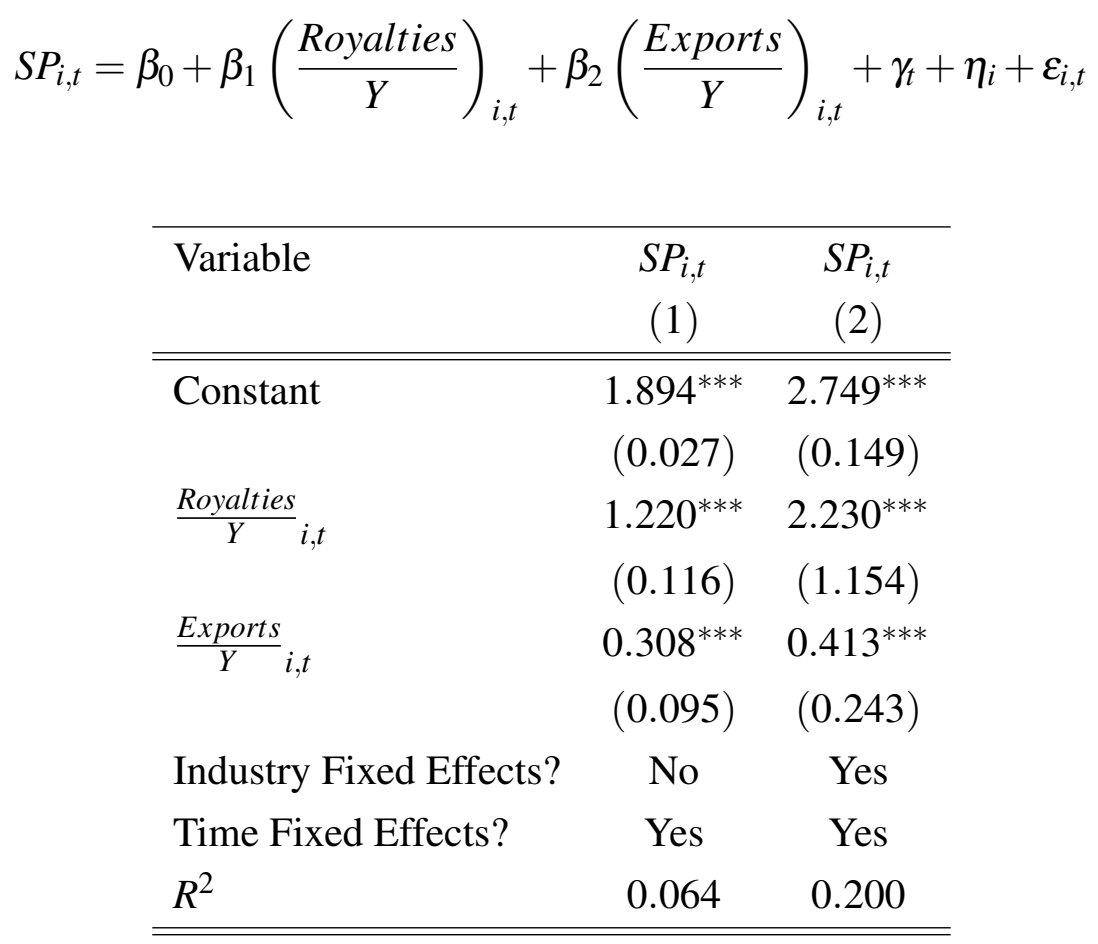

Table 1: Regression Results

* significant at the $10 \%$ level, ** significant at the 5\% level, *** significant at the $1 \%$ level

Table 1 reflects that this estimation mimics what other authors have found. In particular, exporting is associated with increasing skill premia when we do not consider other sources of variation. Moreover, royalties are positively correlated with increasing skill premia, indicating that those industries that make large payments for technology rental (as a percentage of output) have, on average, higher skill premia. In order to test whether integration into supply chains is an important determinant of the skill premium, I include both imports of intermediates and exports of intermediates and estimate the following equation.

$$
S P_{i, t}=\beta_{0}+\beta_{1}\left(\frac{\text { Royalties }}{Y}\right)_{i, t}+\beta_{2}\left(\frac{\text { Exports }}{Y}\right)_{i, t}+\beta_{3}\left(\frac{\text { Imports }}{Y}\right)_{i, t}+\gamma_{t}+\eta_{i}+\varepsilon_{i, t}
$$

From Table 2, we can see that including intermediate imports negates the effects of exporting. 
In particular, the coefficient on exporting becomes negative, which is in line with the StolperSamuelson predictions, whereas the coefficient on intermediate imports is positive, statistically significant, and large. So, exporting in the absence of intermediate imports is associated with low skill premia and importing of intermediate inputs is associated with high skill premia.

\begin{tabular}{lcc}
\hline Variable & $\begin{array}{c}S P_{i, t} \\
(1)\end{array}$ & $\begin{array}{c}S P_{i, t} \\
(2)\end{array}$ \\
\hline \hline Constant & $2.783^{* * *}$ & $2.695^{* * *}$ \\
& $(0.030)$ & $(0.151)$ \\
$\frac{\text { Royalties }}{Y}_{i, t}$ & $1.451^{* * *}$ & $2.518^{* * *}$ \\
& $(0.118)$ & $(1.157)$ \\
$\frac{\text { Exports }}{Y}_{i, t}$ & $-1.251^{* * *}$ & -0.305 \\
$\underbrace{Y}_{\text {Imports }}$ & $(0.378)$ & $(0.369)$ \\
& $2.549^{* * *}$ & $1.378^{* * *}$ \\
Industry Fixed Effects? & $(0.317)$ & $(0.532)$ \\
Time Fixed Effects? & No & Yes \\
$R^{2}$ & Yes & Yes \\
\hline \hline
\end{tabular}

Table 2: Regression Results

* significant at the $10 \%$ level, ** significant at the $5 \%$ level, *** significant at the $1 \%$ level

I interpret these results as indicating that supply chains are an important determinant of skill premia. In light of this evidence, I build a model in which importing plays a role in determining the skill premium. I am going to think of this as importing "ideas" or technology. Those plants that export intermediate goods are going to need to use imported ideas in order to produce intermediate goods for the final goods producer in the other country. I will have two sectors: one which is high-skill-intensive and on which is low-skill intensive. The two sectors are important to allow for the existence of standard Stolper-Samuelson effects. There will be a single market for each type of labor, so all plants will experience the same increase in the skill premium, but the increase in the skill premium in Mexico will be driven by the the sector which integrates into the supply chain of the United States and shares the technology of the U.S. final goods producers. One sector will not integrate into the supply chain of the other country, though there will be trade in the final goods produced by both sectors, and this will produce the standard Stolper-Samuelson effect. The relative importance of technology in production will determine the size of the increase of the skill premium. 


\section{The Model Environment}

My model economy features two countries, Mexico (denoted by $M$ ) and the United States (denoted by $U$ ), and $I$ industries, indexed by $i$. In each country and industry, there is a tradeable final good produced by perfectly competitive firms. This final good is a CES aggregate of a continuum of varieties, some of which are produced domestically and some of which are imported and subject to a iceberg transportation cost. The final good can be used either for consumption or for investment in the stock of technology capital, which is used in production of the intermediate varieties. The production of these varieties requires skilled and unskilled labor, as well as the afroementioned technology capital. The producer of an individual variety is a monopolistic competitor and may produce that variety for a domestic final goods producer and for a foreign final goods producer at the same time, meaning that they may operate two different technologies within a single firm. I will refer to the operation of different technologies within a single variety as production lines within that variety or firm. Aggregate labor of each type is inelastically supplied and is immobile across countries, thought it is perfectly mobile across industries and production lines. I will allow certain parameters to vary across industries but the producers of varieties within an industry will be identical, due primarily to data constraints. I now provide details of the model environment.

\section{Final Goods Producers}

In each industry and each country, there are perfectly competitive producers of a tradeable final good which seek to maximize the infinite sum of discounted dividends. The final good in country $k$ and industry $i$ is denoted $Y_{k i}$ and is composed of a CES aggregation of intermediate varieties $y_{k j i}(\omega)$, where the variety is denoted by $\omega$ and the country of origin for that particular variety is indexed by $j$. The final goods producer owns and invests in a stock of technology capital, $Z_{k i}$, which it rents to the producers of the intermediate varieties of which its final good is composed. It earns returns $r_{k k i}$ and $r_{k j i}$ from renting its technology capital to domestic and foreign producers of intermediate varieties, respectively. To economize on notation, I will suppress the time subscript. These final goods producers in country $k \in\{U, M\}$ and industry $i$ solve the following problem:

$$
\max \sum_{t=0}^{\infty} P_{k i} D_{k i}
$$

s.t. 


$$
\begin{aligned}
D_{k i} & =Y_{k i}-I_{k i}+Z_{k i}\left(r_{k k i}+r_{k j i}\right)-\int_{\Omega_{i}} p_{k j i}(\omega) y_{k j i}(\omega) d \omega \\
I_{k i} & =Z_{k i}^{\prime}-(1-\delta) Z_{k i} \\
Y_{k i} & =\left[\int_{\Omega_{i}} y_{k j i}^{d}(\omega)^{\rho} d \omega\right]^{1 / \rho}
\end{aligned}
$$

where $\frac{1}{1-\rho}$ is the elasticity of substitution between varieties within each sector. A variety $\omega$ is country specific and final producer will purchase varieties from both countries, substituting towards more domestic varieties if the cost of foreign intermediates is higher.

\section{Technology Capital: Investment and Rental}

The technology capital that I consider, $Z_{k i}$, can be thought of as a stock of ideas, blueprints, or production techniques and, as such, is non-rivalrous in nature. These production techniques are the ones that are necessary in order to make an intermediate part for the final product so when the final goods producer begins to purchase more intermediates from foreign producers, the foreign producer will have to rent more of this technology capital in order to produce these parts. This causes the rate of return on technology capital to increase for the final goods producer, thus inducing them to increase investment in it. Moreover, the rental of technology capital in order to produce the appropriate part for the foreign final goods producer is the channel by which this technology capital will be transferred across borders.

I assume that this technology is high skill augmenting and low skill saving. This assumption is based on the large literature that shows that technological advancements since the early 1980s have favored high skill workers. I extend this observation to technology capital, assuming that production techniques have changed the mix of high and low skill workers. The extent to which this is true in the model will depend on parameter values, which will be discussed in detail in what follows.

\section{Production of Varieties}

The intermediate goods producer that produces intermediate variety $\omega$ for industry $i$ in country $k$ can produce both for the domestic market $(k)$ and for the foreign market $(j)$. He chooses output for the domestic market $\left(y_{k k i}(\omega)\right)$, output for the foreign market $\left(y_{j k i}(\omega)\right)$, skilled labor to produce for the domestic market $\left(h_{k k i}(\omega)\right)$, skilled labor to produce for the foreign market $\left(h_{j k i}(\omega)\right)$, unskilled 
labor to produce for the domestic market $\left(l_{k k i}(\omega)\right)$, unskilled labor to produce for the foreign market $\left(l_{j k i}(\omega)\right)$, and amount of domestic and foreign technology $\left(Z_{k i}, Z_{j i}\right)$ to maximize profits, taking the inverse demand function, wages $\left(w_{k}^{H}, w_{k}^{L}\right)$, and the rental rates for technology $\left(r_{j k i}, r_{k k i}\right)$ as given. The first subscript refers to the country for which the intermediate variety is produced and the second refers to the country in which production takes place. The producer of the intermediate good must use the technology of the supply chain that they are supplying in order to produce the variety for that firm.

$$
\max \sum_{j \in\{U, M\}} \frac{p_{j k i}(\omega)}{\tau_{j k i}} y_{j k i}(\omega)-w_{k}^{H} h_{j k i}(\omega)-w_{k}^{L} l_{j k i}(\omega)-Z_{j i} r_{j k i} \tau_{j k i}^{z}
$$

s.t.

$$
\begin{array}{ll}
y_{j k i}(\omega)=A_{j}\left[\theta_{i}\left(Z_{k i}^{\alpha} h_{j k i}^{1-\alpha}(\omega)\right)^{\frac{\sigma-1}{\sigma}}+\left(1-\theta_{i}\right) l_{j k i}(\omega)^{\frac{\sigma-1}{\sigma}}\right]^{\frac{\sigma}{\sigma-1}} \quad \forall j \in\{U, M\} \\
y_{j k i}(\omega)=\left(\frac{p_{j k i}(\omega)}{P_{j i}}\right)^{\frac{1}{\rho-1}} Y_{j i} \quad \forall j \in\{U, M\} &
\end{array}
$$

where $\sigma>0$ is the elasticity of substitution between high and low skilled labor. The skill-intensity of production will be jointly governed by $\alpha \in(0,1)$ and $\theta_{i} \in(0,1)$, as will be discussed in more detail below. $A_{k} \geq 0$ is the level of country-specific total factor productivity (TFP) and $P_{j i}$ is the cost of the final good produced in industry $i$ in country $j$, the country for whose supply chain the intermediate variety is being produced. There are two wedges on the production, $\tau_{j k i}$ and $\tau_{j k}^{z}$, which are both equal to one if the variety is produced for the domestic final goods producer $(j=k)$ and greater than one otherwise $(j \neq k)$. The first of these is an iceberg trade cost on goods and the second can be thought of as an implicit tax on the use of foreign technology. This implicit tax is a stand-in for imperfect intellectual property protection. As detailed in Section 2, part of the liberalization between the United States and Mexico was the adoption of stricter protection of intellectual property by Mexican firms; $\tau_{j k}^{z}$ is included in order to capture this feature.

\section{Aggregation and Market Clearing}

Final output in each industry $i$ must equal world demand for consumption and investment from that industry

$$
\sum_{k \in U, M} Y_{k i}=\sum_{k \in U, M}\left[c_{k i}+I_{k, i}\right] \quad \forall i \in I
$$


and total output for each variety $\omega$ must in each industry $i$ must equal its world demand

$$
y_{k k i}(\omega)+y_{j k i}(\omega)=y_{k k i}^{d}(\omega)+\tau_{j k i} y_{k j i}^{d}(\omega) .
$$

Labor market clearing in each country requires that the labor used to produce all varieties in country $k$ for the domestic production line and for the foreign production line across all industries $i$ is equal to the aggregate inelastic supply of high and low skilled labor respectively

$$
\begin{aligned}
H_{k} & =\sum_{i \in I} \int_{\Omega_{i}}\left(h_{k k i}(\omega)+h_{j k i}(\omega)\right) d \omega \\
L_{k} & =\sum_{i \in I} \int_{\Omega_{i}}\left(l_{k k i}(\omega)+l_{j k i}(\omega)\right) d \omega .
\end{aligned}
$$

Recall that a firm producing variety $\omega$ may produce both for the domestic production line $\left(y_{k k i}(\omega)\right)$ and for the foreign one $\left(y_{j k i}(\omega)\right)$.

\section{Equilibrium}

An equilibrium of the world economy is a set of prices $P_{k i}, p_{k j i}(\omega)$; wages $w_{k}^{H}, w_{k}^{L}$; rental rates for technology capital $r_{k j i}$; demand for labor $h_{j k i}(\omega), l_{j k i}(\omega)$; quantities demanded $y_{k j i}^{d}(\omega)$; demand for consumption and investment $c_{k i}, I_{k i}$; and quantities produced $Y_{k i}, y_{j k i}(\omega)$ that satisfy, in each country: dividend maximization by the final goods producer (Equations (1) through (4)); profit maximization by the intermediate goods producers (Equations (5) through (7)); utility maximization by the consumer (Equations (17) and (18) in the Appendix); and goods, labor, and bond market clearing conditions (Equations (8) through (11) and Equation (19) in the Appendix).

\section{Skill Premium}

The skill premium in Country $k$ in this model can be expressed as

$$
\frac{w_{k}^{H}}{w_{k}^{L}}=(1-\alpha) \frac{\theta_{i}}{1-\theta_{i}}\left(\frac{Z_{j i}}{h_{j k i}}\right)^{\alpha \frac{\sigma-1}{\sigma}}\left(\frac{h_{j k i}}{l_{j k i}}\right)^{\frac{-1}{\sigma}}
$$


where I denote by $h_{j k i}$ and $l_{j k i}$ the equilibrium choices for high and low skilled labor that are made by all firms in industry $i$ producing in country $k$ for the supply chain of country $j$. Recall that producers of all varieties $\omega$ in a particular industry are identical so their equilibirum choices will be the same; therefore, I suppress the notation indicating the variety. Because labor is perfectly mobile across all industries, wages will equalize across industries and this equation will hold for

every industry $i$. In the expression above, we can think of the term $\left(\frac{Z_{j i}}{h_{j k i}}\right)^{\alpha \frac{\sigma-1}{\sigma}}$ as representing the relative demand for high-skill labor and $\left(\frac{h_{j k i}}{l_{j k i}}\right)^{\frac{-1}{\sigma}}$ as representing the relative supply of labor in industry $i$. The demand will be affected by the amount of technology being utilized in a given country and industry and the supply will be subject to the normal Stolper-Samuelson forces.

In what follows, for simplicity, I will consider only two industries $i \in\{1,2\}$ with Industry 1 being relatively high-skill intensive and Industry 2 being relatively low-skill intensive $\left(\theta_{1}>\theta_{2}\right)$. The results and logic will extend to the multi-industry case.

\section{Standard H-O}

Suppose for the moment that $\alpha=0$. In this case, technology capital is not used at all in production and the expression for the skill premium simplifies to

$$
\frac{w_{k}^{H}}{w_{k}^{L}}=\frac{\theta_{i}}{1-\theta_{i}}\left(\frac{h_{j k i}}{l_{j k i}}\right)^{\frac{-1}{\sigma}}
$$

which is equivalent to the skill premium in the standard $\mathrm{H}-\mathrm{O}$ model and the logic from the $2 \times 2 \times 2$ $\mathrm{H}-\mathrm{O}$ model follows. Meixco is relatively abundant in low-skill labor while the United States is relatively abundant in high-skill labor. Therefore, absent any role for technology, i.e. $\alpha=0$, when countries are in autarky, the relative wages are completely determined by the aggregate supply of factors in the country and the skill premium will be higher in Mexico. Once the countries open to trade, because it's relatively less expensive to make the low-skill intensive good in Mexico, the low-skill abundant country, Mexcio will move towards specializing in producing goods from Industry 2. Likewise, the United States will move towards specializing in the production of goods for Industry 1 since it is less expensive to produce that good in the United States than in Mexico. If both countries were to completely specialize in the producing their respective goods, meaning that the entire labor force would be dedicated to production in that industry, the skill premia in the 
United States and Mexico would become

$$
\begin{aligned}
\frac{w_{U}^{H}}{w_{U}^{L}} & =\frac{\theta_{1}}{1-\theta_{1}}\left(\frac{H_{U}}{L_{U}}\right)^{\frac{-1}{\sigma}} \\
\frac{w_{M}^{H}}{w_{M}^{L}} & =\frac{\theta_{2}}{1-\theta_{2}}\left(\frac{H_{M}}{L_{M}}\right)^{\frac{-1}{\sigma}}
\end{aligned}
$$

Because there would have been some portion of the labor force producing for each industry in autarky in order to satisfy demand for both goods, the movement to specialization drives the skill premium down in the United States and up in Mexico. ${ }^{3}$ This is true even in the case of incomplete specialization, as the result is driven by the facts that $\theta_{1}>\theta_{2}$ and that a greater proportion of the labor force being dedicated to the high-skill intensive industry in the United States and a greater proportion of the labor force working in the low-skill intensive industry in Mexico after trade liberalization.

\section{Role of Technology Capital}

Now, if $\alpha>0$, technology capital will be a necessary part of the production process, the skill premium will be expressed as in Equation (12), and the relative demand for labor will therefore be affected by technology capital. In order to understand how the skill premium is impacted by a trade liberalization, first note that if $\sigma>1$ and $Z_{j i}$ increases following liberalization, then the skill premium will increase, all else equal. Therefore, an increase in technology capital may offset or completely overturn the pressure on the skill premium that arises due to labor reallocation across industries. Moreover, the increased availability of more productive technology due to a decrease in trade barriers will decrease the incentive for labor to reallocate across industries.

There are two forces that may cause technology capital in the world to increase. The first is what I refer to as the "adoption channel" whereby Mexican producers upgrade to using the more skillintensive technology of the U.S. final goods producers in order to produce for their supply chain. This occurs as the tariff on the intermediate good produced for the U.S. $\left(\tau_{j k i}\right)$ falls or the distortion to the use of the U.S. technology capital $\left(\tau_{j k i}^{z}\right)$ falls. A reduction in either distortion results in the Mexican intermediate goods producer shifting towards producing more for the U.S. final goods producer than they did pre-liberalization.

The second force is what I refer to as the "investment channel," which is the increase in investment in technology capital by the final goods producer that will occur as a result of an increase

\footnotetext{
${ }^{3}$ See appendix for details.
} 
in the rental rate for that technology. As barriers to trade fall, the technology of the United States will begin to be used more intensively in Mexico as discussed above. This increases the return to investing in that technology for the American final goods producers. All else equal, these producers will increase investment in their technology capital. This is a secondary driver of increased technology in Mexico and the primary driver of increased technology in the United States.I will explore each of these pieces through some simple comparative statics. I will provide the intuition in what follows, while details can be found the the appendix.

\section{Adoption Channel}

In order to see how the adoption channel operates, suppose for the moment that there is only one industry, $i$, so high and low skilled laborers are fully employed therein and there is no reallocative pressure from the H-O mechanism discussed above. Changes both to the tariff, $\tau_{j k i}$, and to the distortion to the use of foreign technology capital, $\tau_{j k i}^{z}$, will contribute to the adoption channel. Suppose first that there is a reduction in the tariff on the good and consider the problem of the final goods producer in the United States (Equations 1 through 4). Because the intermediate goods producers are monopolistic competitors, they will charge a constant mark-up over marginal cost, $c\left(w_{k}^{H}, w_{k}^{H}, r_{k k i}, r_{j k i}\right)$ :

$$
p_{j k i}=\rho \tau_{j k i} c\left(w_{k}^{H}, w_{k}^{H}, r_{k k i}, r_{j k i}\right)
$$

When the tariff falls, all else equal, the effective price paid by the final goods producer for the Mexican intermediate will also fall, therefore increasing the amount that the U.S. final goods producer demands from the Mexican intermediate firm. In order to meet this demand, the Mexican intermediate goods producer must rent more of the U.S. technology capital, $Z_{U i}$, and allocate more labor to producing for the U.S. production line, which is more skill intensive $\left(Z_{U i}>Z_{M i}\right)$ since the autarkic levels of technology capital will be determined by the skill level in country. This reallocation towards producing for the U.S. final good will, therefore, increase the skill premium in Mexico.

To see the second way in which the adoption channel might be activated, consider the intermediate goods producer's problem in Mexico (Equations 5 through 7) and suppose that there is a reducion in the distortion to foreign technology capital. The intermediate goods producer is effectively paying a tax on his use of foreign technology capital, $Z_{U i}$. As the distortion on that technology capital falls, it becomes less costly for him to produce for the foreign final goods producer. Therefore, all else equal, he will reallocate resources toward that production line. This will 
again cause the producer to adopt more U.S. technology capital, thus affecting the skill premium as before.

\section{Investment Channel}

In order to understand the investment channel, consider the expression for the rental rate for the U.S. technology $\left(Z_{U i}\right)$ being used in Mexico by an intermediate goods producer for Industry $i$

$$
r_{j k i}=\rho \theta_{i} \alpha \frac{p_{j k i}(\omega)}{\tau} A_{j}\left[\theta_{i}\left(Z_{k i}^{\alpha} h_{j k i}^{1-\alpha}\right)^{\frac{\sigma-1}{\sigma}}+\left(1-\theta_{i}\right) l_{j k i}^{\frac{\sigma-1}{\sigma}}\right]^{\frac{1}{\sigma-1}} Z_{k i}^{\frac{\alpha(\sigma-1)}{\sigma}}-1 h_{j k i}^{\frac{(1-\alpha)(\sigma-1)}{\sigma}}
$$

where

$$
\tau=\tau_{j k i}^{z} \tau_{j k i}
$$

As can be seen in Equation (16), the tariff on the good and the tax on technology capital serve to reduce the return to renting technology across borders. Therefore, as either of these distortions decrease, the return to investing in the technology capital increases, thus increasing the U.S. final goods producer's investment. The key assumption here is that the technology capital is nonrivalrous and so the total return to investing in it is equal to the sum of the return in each country. All else equal, the domestic return will be unaffected by the reduction of the trade distortions, while the foreign return will increase. This means that the total return increases, incentivizing the final goods producer to increase the stock of technology capital.

\section{Calibration and Quantitative Results}

I now turn to the calibration of the model and the implications of the calibrated model for the key observations in both countries. Additionally, I discuss sensitivity of the results to the selected calibration.

\subsection{Calibration}

I now calibrate the model to quantify the extent to which it can account for the increase in the skill premia. Table 3 details the fixed parameter values chosen, as well as the source for these parameter 
selections.

\begin{tabular}{ccc}
\hline Parameter & Value & Source \\
\hline \hline$\beta$ & 0.96 & Annual return on risk-free bonds \\
$\rho, \phi$ & 0.63 & Trade literature \\
$\delta_{j}$ & 0.08 & McGrattan \& Prescott \\
$A_{M}$ & 0.25 & Relative value-added per worker in 1985 \\
$H_{U}$ & 0.28 & CPS - Fraction of Population with Some College 1985 \\
$H_{M}$ & 0.09 & ENOE - Fraction of Population with Some College 1985 \\
$L_{U}$ & 0.72 & CPS - Fraction of Population with No College 1985 \\
$L_{M}$ & 0.91 & ENOE - Fraction of Population with No College 1985 \\
\hline \hline
\end{tabular}

Table 3: Fixed Parameter Values

Some of these parameters deserve discussion. In particular, I calculate the relative total factor productivity (TFP) in Mexico $\left(A_{M}\right)$ to be 0.25 . Note that I normalize TFP in the United States to be 1 . I then calculate the relative value added per worker in the manufacturing sector in Mexico in 1985. I choose the manufacturing sector instead of the overall economy because my skill premium data pertains to the manufacturing sector only. For the relative supply of high-skilled workers, I use the household surveys that are available for both countries. The data analog to high-skilled workers are non-production employees. Since these are defined to be managers and technicians, I look at individuals with some college. This includes individuals with technical training. I do not want to rely on the ratio of non-production to production employees in manufacturing because this is an equilibrium outcome which is reflective of the skill intensity of manufacturing. While both countries have similar ratios of non-production to production employees in manufacturing, the ratio of college to non-college individuals differs substantially across the two. I utilize this difference in order to rationalize the large observed difference in initial skill premia. The rate of time discounting $(\beta)$ and the substitutibility of intermediate goods $(\rho, \phi)$ are taken directly from the literature. The model unit of time is one year. Although changing these parameters would affect the initial calibration, they do not impact the qualitative results in terms of changes in skill premia. Moreover, the initial calibration is not particularly sensitive to these parameter choices. As in McGrattan and Prescott (2009), $\delta$ is not separately identified from $\alpha$; the parameters jointly determine the return to technology capital. I am going to hold fixed $\delta$ and conduct sensitivity analysis on $\alpha$ but it should be noted that each value of $\alpha$ is dependent upon the associated rate of depreciation, $\delta$.

The most important parameters for the results are technology capital's share of income $(\alpha)$ and 


\begin{tabular}{ccc}
\hline Parameter & Value & Interpretation \\
\hline \hline$\frac{\omega_{y}}{\omega_{x}}$ & 1.41 & Relative Skill Intensity of the Sectors \\
$\alpha$ & 0.39 & Technology Capital's Share \\
$\sigma$ & 1.98 & Elasticity of Substitution between H \& L \\
\hline \hline
\end{tabular}

Table 4: Calibrated Parameters

the elasticity of substitution between high- and low-skill labor $(\sigma)$. Also important is the ratio of the factor share parameters in the production function $\left(\frac{\omega_{y}}{\omega_{x}}\right)$ which determines how relatively skill intensive each sector is. In order to pin these parameters down, I match three moments in the data: (1) the ratio of royalties to payroll in Mexico in 1985; (2) the Mexican skill premium in 1985; and (3) the U.S. skill premium in 1985. I match the parameters via the general method of moments (GMM).

\begin{tabular}{ccc}
\hline Moment & Data & Model \\
\hline \hline Ratio of Royalties to Payroll - Mexico 1985 & 0.055 & 0.058 \\
Skill Premium - Mexico 1985 & 2.03 & 2.03 \\
Skill Premium - U.S. 1985 & 1.42 & 1.42 \\
\hline \hline
\end{tabular}

Table 5: Target Moments

Table 4 shows the parameter values resulting from the calibration exercise and Table 5 displays the targeted moments in the data and the model's fit with them. As Table 5 shows, the model hits the target moments. The estimated elasticity of substitution between high- and low-skill labor is in keeping with estimates from the literature, though it is on the high side of the acceptable range. I assume that the elasticity of substitution is the same across countries. Likewise, I assume that technology's share of income is the same across countries. I do this for two reasons. The first is that I have data on royalty payments only for Mexican manufacturing. Because royalty payments over payroll is the obvious data analog to technology's share of income, I want to match this moment precisely in order to discipline $\alpha$. In the absence of royalty data, I have no way of pinning down this parameter. The second reason is that these two parameters $(\alpha, \sigma)$ are the parameters to which my model results are most sensitive. I do not want the difference in production functions to be driving the results. I will conduct sensitivity analysis to the choice of these variables but will not allow them to vary across countries. 


\subsection{Results}

I now conduct an experiment in which I move the countries from the fully closed economy (autarky) to the one with no barriers to trade or technology flow $\left(\tau_{y}, \tau_{z}=0\right)$. This is the extreme case and will serve as an an upper bound on the extent to which the increase in the skill premia can be accounted for by the proposed mechanism.

\begin{tabular}{ccccccc}
\hline & \multicolumn{2}{c}{ Closed } & \multicolumn{2}{c}{ Trade in Goods \& Technology } & \multicolumn{2}{c}{$\% \Delta$} \\
& Data & Model & Data & Model & Data & Model \\
\hline \hline Mexico & 2.03 & 2.03 & 3.1 & 2.8 & 50.4 & 39.4 \\
U.S. & 1.42 & 1.38 & 1.6 & 1.5 & 11.0 & 8.0 \\
\hline \hline
\end{tabular}

Table 6: Results - Autarky to Free Trade

As Table 6 shows, the model is able to capture over two thirds of the rise in the skill premium in Mexico and in the skill premium in the United States. For contrast, in Table 7, I report the rise in the skill premium that occurs in the model without technology capital $(\alpha=0)$, which is the $\mathrm{H}-\mathrm{O}$ analog. Here, I use the same values for $\omega_{y}, \omega_{x}$, and $\sigma$ as in the model with technology capital and simply set $\alpha=0$. This implies that the initial steady state will not match the target moments, so I only report the percent change between the closed and open steady states, not the levels. In this case, the Stolper-Samuelson effect is present for Mexico; the skill premium in Mexico in the open economy is $10 \%$ lower than it is in autarky. You will notice that, perhaps surprisingly, the increase in the skill premium in the United States is smaller in the world without technology capital. This means that the Stolper-Samuelson effects are not the main driver of the increase in the skill premium in the United States. There are two reasons for this. First, is the investment channel that I explored above serves to increase the skill premium. Second, the Stolper-Samuelson effects are not as strong here as they would be in the most basic $\mathrm{H}-\mathrm{O}$ model. This is because, here, intermediate inputs are relative complements, and in the most basic $\mathrm{H}-\mathrm{O}$ model, there are only two goods which are substitutes for one another. Therefore, when industries integrate, the intermediate inputs from the two countries are relative complements and so there is a tendency for demand for the factors of production to move in the same direction in the two countries. This implies that the fact that Sector $Y$ integrates is, in part, responsible for the skill premia moving in the same direction in both countries. In the absence of technology capital, however, the increased (world) supply of unskilled workers dominates and the skill premium falls. There are parameter values for which the skill premium rises in the United States and falls in Mexico. However, the skill premium in the United States never rises as much as it would in a world in which goods are gross substitutes. 


\begin{tabular}{cccc}
\hline \multicolumn{3}{c}{$\% \Delta$} \\
Data & \multicolumn{2}{c}{ Model } \\
& & With $Z$ & No $Z$ \\
\hline Mexico & 50.4 & 39.4 & -9.78 \\
U.S. & 11.0 & 8.0 & 1.00 \\
\hline \hline
\end{tabular}

Table 7: Results - Baseline Model vs H-O Analog

Figure 5a shows the fit of the skill premium in the model relative to the data and its transition path from one steady state to the next. The red lines correspond to Mexico and the blue lines correspond to the United States. Consider first the output for Mexico. The line with circular markers denotes the data and the solid line corresponds to my baseline model. Notice that, while the baseline model features a smooth transition between the autarkic steady state and the free trade steady state, the initial jump in the skill premium in the first period is pronounced. This is due to the fact that there is no cost to the producers of the intermediate goods for switching from producing for the Mexican supply chain, which uses the Mexican technology capital, $Z_{M, y}$, to producing for the American supply chain, which uses the U.S. technology, $Z_{U, y}$. Because the more advanced technology becomes immediately adopted, there is a large initial jump in the skill premium. This is the adoption channel at play. The rest of the increase in the skill premium is driven by the investment channel. As the U.S. invests more and more into the stock of U.S. technology capital, $Z_{U, y}$, Mexican firms continue to adopt this technology. This additional adoption would not happen, however, if the U.S. were not investing additional resources into $Z_{U, y}$. For contrast, I have also included the results for the world without technology capital (setting $\alpha=0$ but keeping all other parameter values fixed at the calibrated values), which is the basic H-O model. This is represented by the red dashed line for Mexico. Notice that in the absence of technology capital, the skill premium falls immediately. This is because there are no dynamics in the basic $\mathrm{H}-\mathrm{O}$ model and so the model transitions immediately to the new steady state, where Mexican firms specialize entirely in the production of the unskilled-intensive good, or the good produced in Sector $X$. The new steady state in the $\mathrm{H}-\mathrm{O}$ world features a falling skill premium in Mexico, just as standard trade theory predicts.

Now, I turn my attention to the results for the United States, which are denoted by the blue lines. Again, the line with circular markers is the data, the solid line is the result of the baseline model, and the dashed line is the result of the basic H-O analog using the calibrated parameter values from the baseline model. We can see in Figure 5a that my baseline model also increases the skill premium in the United State by more than the H-O analog. This is precisely because of 


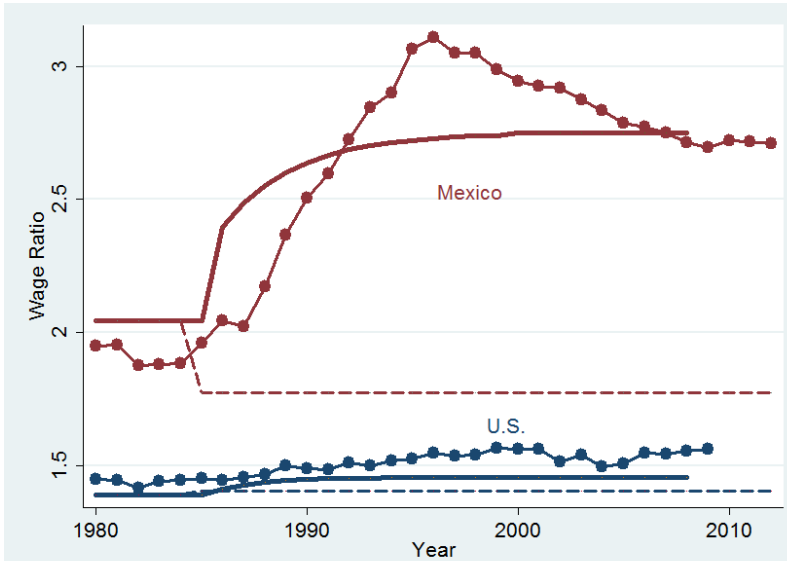

(a) Levels

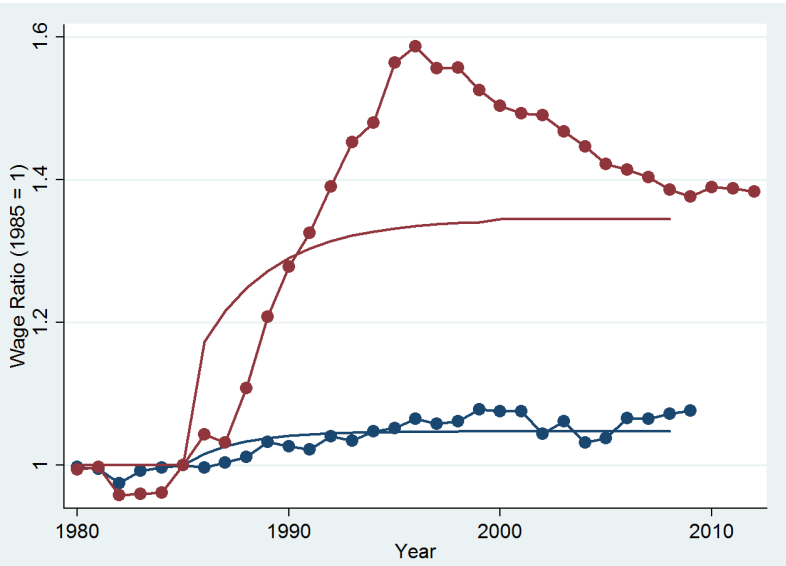

(b) Relative to 1985

Figure 5: Data vs. Model - Skill Premia

the investment channel. In the basic H-O setup, there is an immediate jump in the skill premium due to specialization. Because firms can switch immediately to production of the good in which they have the comparative advantage and there is no dynamic accumulation of any sort of capital (technology or otherwise), the transition from one steady state to the next is immediate. In the model with technology capital, however, there is a slower transition to the new steady state, while the stock of technology capital is being accumulated to its new steady state level. As the Mexican firms adopt more and more of the U.S. technology capital, the return to investing in this technology capital continues to increase. Therefore, the U.S. final goods producer will continue to invest in additional technology capital until the marginal return on that investment is maximized, which occurs once all of the Mexican firms that will switch to producing for the American supply chain have completed their transition. We see this as a gradual transition from the initial closed economy steady state to the one in which supply chains are integrated across countries.

Figure 6 displays the results of the model for imports to and exports from Mexico as a fraction of the value added in manufacturing. In the model, all output is manufacturing output, so the closest data analog is manufacturing imports and exports over value added in manufacturing. Recall that the model does not fully incorporate the back and forth trade that is inherent in supply chain relationships. Therefore, it is natural that the model would underestimate imports and over-estimate exports, since it is not accounting for some of the re-importation that occurs via the supply chain and it is, therefore, over counting the value-added of the exported goods. Exports increase to about $12 \%$ of value added in the data and to about $16 \%$ of value added in the model, while imports increase to about $12 \%$ of value added in the data and to about $4 \%$ of value added in the model. 


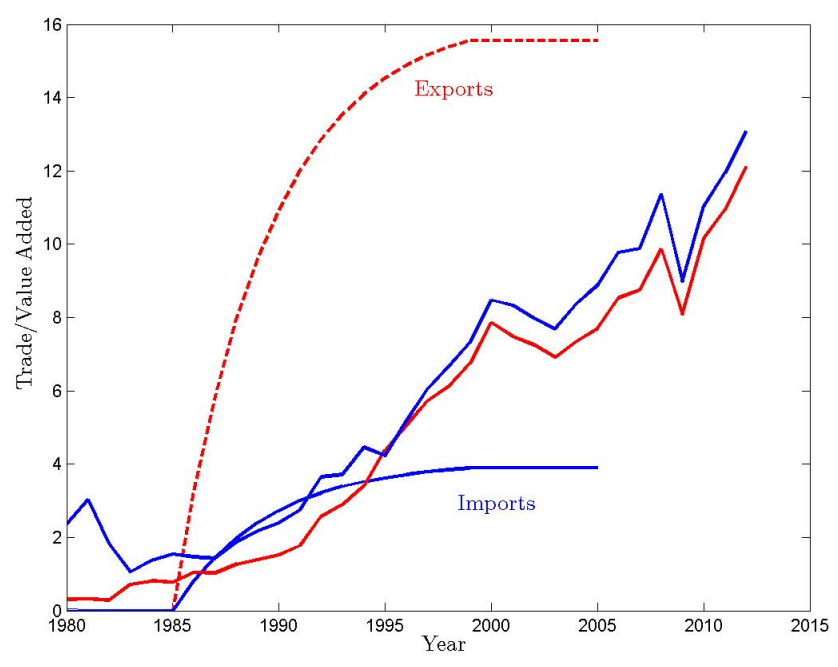

Figure 6: Data vs. Model - Trade

I now turn to the fit of the model with shifts in employment from one sector to the next. In order to compare this measure to the data, I will have to decide which industries belong in the integrated sector (Sector $Y$ ) and which belong in the non-integrated sector (Sector $X$ ). The choice of these industries is not obvious because every industry in Mexico imports some inputs and exports some goods. I do not have data directly linking Mexican firms to their American counterparts, so I cannot directly measure the percentage of firms that are actually part of the U.S. supply chain in the data. Therefore, I instead define the industries using skill-intensity. I have assumed in the model that the integrated sector is the more skill-intensive of the two. Therefore, I use those industries with skill-intensities that are above average to be those industries that are in Sector $Y$. Figure 7 displays the data (solid line) versus the baseline model and the $\mathrm{H}-\mathrm{O}$ analog. As expected, in the $\mathrm{H}-\mathrm{O}$ model, employment in the integrated (skill-intensive) sector falls as Mexico begins to specialize in production of the unskilled-intensive good. In the baseline model, as in the data, employment in the integrated (skill-intensive) sector rises. There is a greater rise in employment in Sector $Y$ in the model than in the data, which may be attributed to the fact that much of the specialization that occurs after trade liberalization occurs within, not across industries (see Goldberg \& Pavcnik, 2007). I have abstracted from heterogeneity across firms within a given sector. Therefore, one would expect to see more intra-industry shifting of employment in the model than in the data. Ideally, I would be able to identify firms as having integrated or not, but this observation is not available in the data.

Recall that the experiment above is for the extreme case of complete autarky to fully open economies. This may not be a bad exercise to do because in the early 1980s, Mexico was one of the most closed economies in the world and by the late 1990s, it was one of the most open and in 


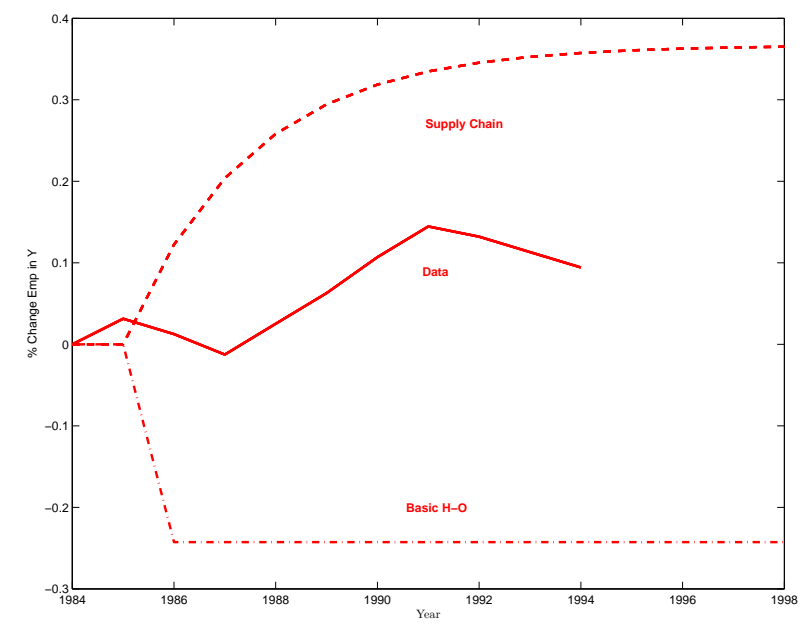

Figure 7: Data vs. Model - Employment

many ways was almost completely integrated into the U.S. market. Notably, full adoption of the intellectual property rights laws of the United States was part of the NAFTA agreement, though Mexico began to adopt these laws as early as 1989 (DuMars, 1991). I view this adoption as one of the important reduction in distortions that occurred to allow supply chains to integrate and final goods producers to share technology with their intermediate goods producers.

In Figure 8, I show the sensitivity of my results to the proposed change in $\tau_{z}$. Recall that moving from autarky to free trade is essentially moving from a high level of distortions to no distortions $\left(\tau_{z}=\infty\right.$ to $\tau_{z}=0$ ). Figure 8 shows how my results would change in a less extreme case. Notice that if these distortions are sufficiently high $\left(\tau_{z}>3\right)$ the Mexican intermediate goods producing firms choose to specialize in producing intermediates for Mexican final goods producers using Mexican technology. If the change in this distortion is sufficiently small, there are no changes in the skill premium due to the "investment channel" in the United States. This is because sufficiently small amounts of U.S. technology are adopted so that the return on technology capital does not change. This, in turn, reduces the firm's incentive to increase investment, thus eliminating the investment channel. As discussed above, the skill premium may rise as a result of integration of supply chains, depending on the relative complementarity of intermediate goods.

\subsection{Sensitivity Analysis}

The most important parameter for determining the change in the skill premium is $\alpha$, as it governs the importance of technology in production and its complementarity with high-skilled labor. Figure 


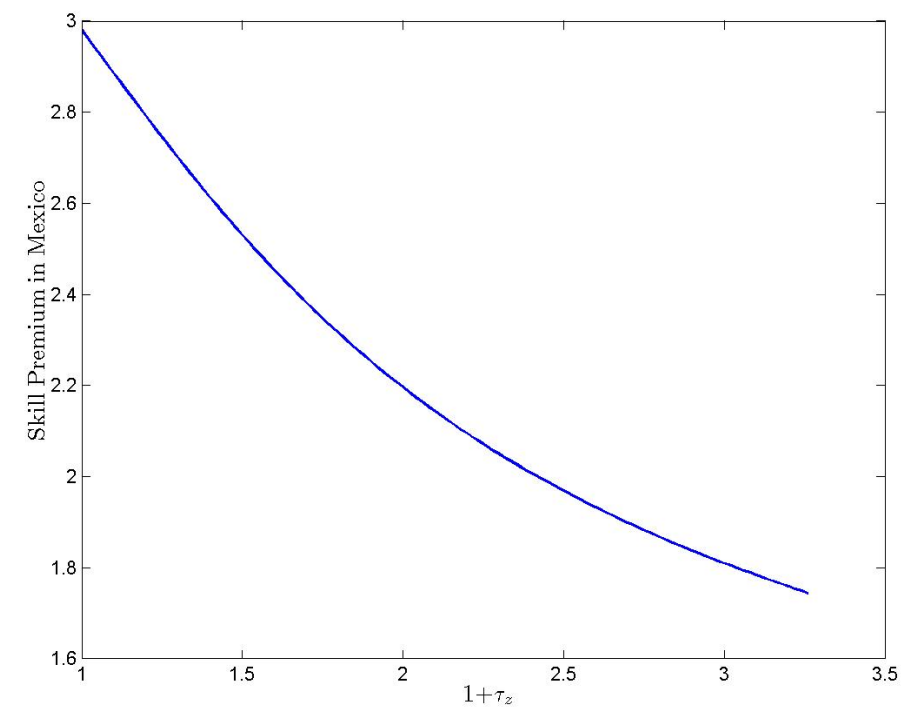

Figure 8: Sensitivity to Changes in $\tau_{z}$

9a shows how the skill premium changes with $\alpha$.

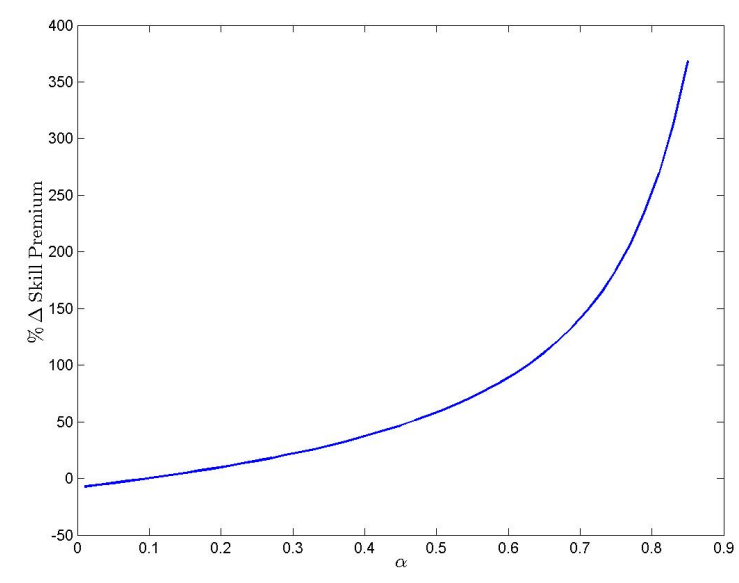

(a) Sensitivity to $\alpha$

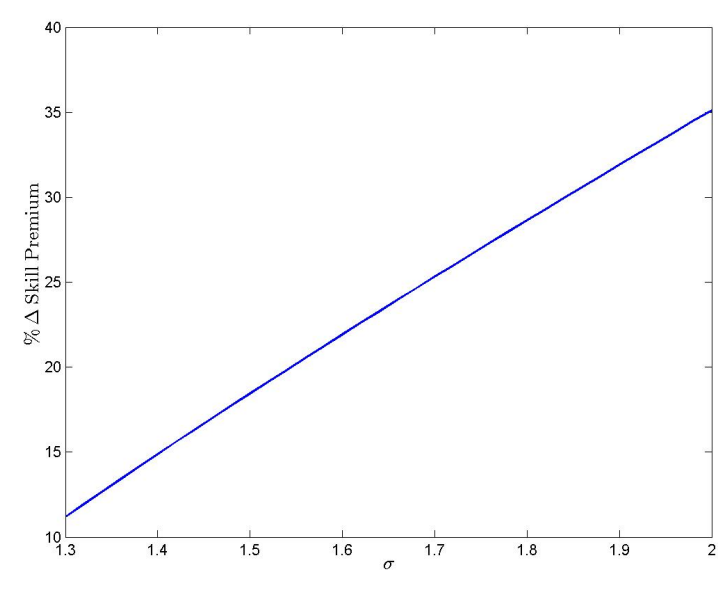

(b) Sensitivity to $\sigma$

Figure 9: Sensitivity of Change in Skill Premium to Technological Parameters

Notice that when $\alpha$ is very close to zero, the Stolper-Samuelson effect dominates and the skill premium in Mexico actually falls as Mexico integrates with the United States. However, as $\alpha$ approaches one, the Stolper-Samuelson effect is no longer important and trade in technology dominates.

Also important for determining the change in the skill premium is $\sigma$, which dictates how substitutable skilled and unskilled labor are. Figure $9 \mathrm{~b}$ shows the sensitivity of the change in the skill 
premium to this variable. Estimates in the data for $\sigma$ range between 1.4 and about 2, so I show that range of value for $\sigma$ on the $\mathrm{x}$-axis of figure $9 \mathrm{~b}$. In Figure 9b, we see that if skilled and unskilled labor are more substitutable, the change in the skill premium is greater in the open economy than if the two types of labor are less substitutable, though the results are not particularly sensitive to this value. Figure 10 shows how the results change when $\alpha$ and $\sigma$ jointly change. As both parameters increase, the change in the skill premium in response to a trade liberalization increases. These parameters cannot be estimated individually from the data, but have to be determined jointly from the calibration procedure. As seen in Figures $9 \mathrm{a}$ and $9 \mathrm{~b}$, the results for the change in the skill premium are much more sensitive to the value of $\alpha$, though the value of $\sigma$ is important matching the initial levels of the skill premia.

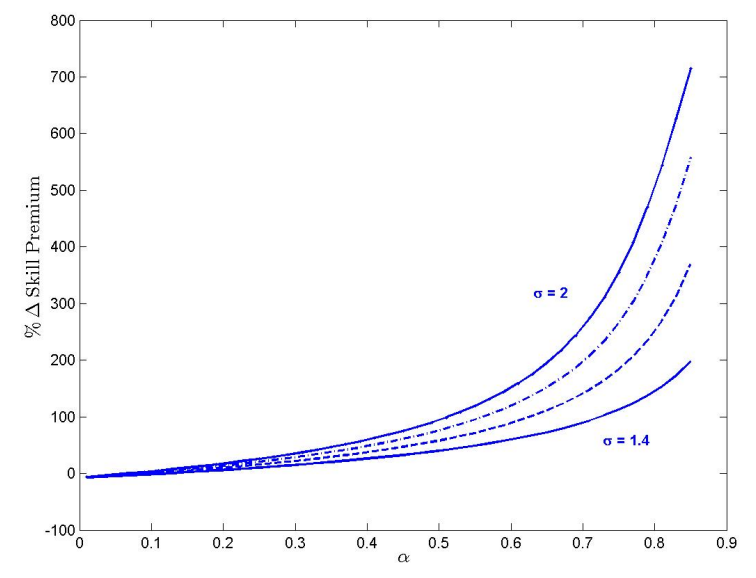

Figure 10: Sensitivity of Changes in Skill Premium to $\alpha$ and $\sigma$

Also of interest is the relative productivity of the trade partner, $A_{M}$. Although this can be directly calculated from the data and so its value is not in question here, it may be of interest so that we can think about how the model would operate when the trade integration is between two countries that are more similar in terms of their initial productivities. In Figure 11, I show how the results change for different levels of productivity. Moreover, in figure 11 if the countries have greater differences in their productivity, trade increases the skill premium in Mexico by much more. This exercise gives implications of the model for the impact of trade in technology between two countries with similar productivities. In particular, if two advanced economies, such as Canada and the United States, were to engage in trade in technology, it would be far less likely that Canada would adopt the technology of the United States to the same extent that Mexico did. The investment channel would still be at work, however, and so there could be a modest rise in the skill level of technology capital in each country, depending on how much of the American technology was used in Canada and vice versa. The increased marginal return to technology capital of 
the final goods producer in the U.S. depends on the Canadian intermediate goods producing firms' willingness to switch from producing for the domestic final goods producer to producing for the American final goods producer. Because the two countries would have initial stocks of technology capital that would be similar, it is unlikely that the return to investing in the technology would change substantially after liberalization. This is broadly consistent with the data on the Canadian manufacturing skill premium following NAFTA. The skill premium in Canada rose by an amount similar to the increase in the skill premium in the U.S.

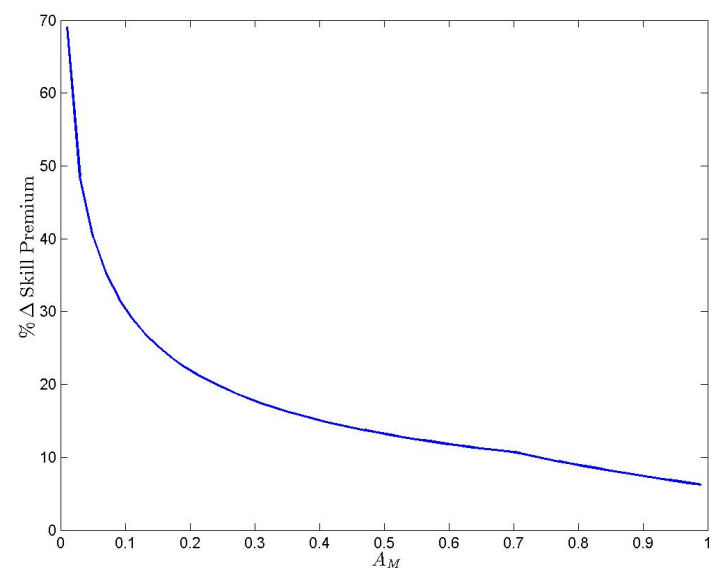

Figure 11: Sensitivity of Changes in Skill Premium to $A_{M}$

The sensitivity analysis suggests that even for values of $\alpha$ and $\sigma$ which are lower than the calibrated values, the model can deliver growth in the skill premium of the sort that we observed over the late 1980s and early 1990s in Mexico. Notice that the sensitivity analysis was all done with respect to changes in the Mexican skill premium. A robust feature of the model is that it delivers a relatively larger increase in the skill premium in Mexico than in the United States, which is a feature that other models of the skill premium lack. The disproportionate rise of the skill premium that occurs in Mexico arises because Mexican intermediate goods producers begin to produce for the supply chain of the U.S. final goods producers, and hence, adopt of these firms. There is an investment effect on the skill premium in both countries, but the majority of the increase in the skill premium in Mexico will come from the adoption of the American technology.

\section{Conclusion}

In this paper, I have shown that integration of supply chains is an important channel by which technology may be shared across countries and, thus, is an important determinant of the impact that a trade liberalization has upon relative wages. The theoretical model that I use to generate 
predictions for the changes in the skill premia following a trade liberalization is a standard twocountry trade model, modified to include technology capital which can be traded across countries. I conclude that, once we consider the trade in technology that inherently occurs as part of integrated supply chains, the increase in the skill premia in both the United States and Mexico, with a disproportionate increase in the Mexican skill premium, is not a puzzle. The model predicts that, while the skill premium rises in both countries, it rises in Mexico by much more than the skill premium in the United States. I have provided evidence of supply chain linkages, as well as evidence that these linkages are important predictors of technological transfer and increasing skill premia. I have further shown that the patterns observed empirically are quantitatively consistent with those predicted by this theory.

My model embeds the standard Heckscher-Ohlin forces and when I shut down the importance of technology in production, I find the standard prediction of a falling skill premium in the Mexico and a rising skill premium in the United States. Allowing for trade in technology overturns this result because it allows for technology adoption in Mexico to spur increases in investment in that same technology in the United States. A key reason that this was possible in the case of Mexico is Mexico's adherence to U.S. intellectual protection laws, which decreased the distortions to using American technology in Mexico. This has implications for other trade relationships and liberalizations. Perhaps the reason that we do not observe such large increases in the skill premium in other developing countries as they open to trade is that trade in technology is hindered by the lack of intellectual property protection in those countries. In future work, I to plan micro-found the distortion to the use of U.S. technology in Mexico and then to extend the analysis to other countries whose skill premia rose following trade liberalizations, such as Chile and Colombia, but by much more modest amounts than the increase observed in Mexico. As a first pass, it is evident that these countries conduct far less intra-industry trade with the developed world than Mexico does, which indicates that their firms are far less integrated into the supply chains of the advanced economies.

The framework developed here can be extended along a number of dimensions. An interesting avenue for future research would be to model the strategic interaction between the final goods producer and the intermediate goods producer which gives rise to the distortion on the use of technology capital in the foreign country, $\tau_{z}$. Better understanding of this relationship will provide a framework to explore the disparate responses to trade liberalization across countries. Another possible extension would be to allow for heterogeneity in some exogenous productivity at the firm-level. Burstein and Vogel (2010) show that reallocation across firms can have an impact on inequality. Allowing for this feature in my current framework would allow me to use more of the plant-level data to test the accuracy of the model. Moreover, it would allow me to study how technology capital gets allocated across intermediate goods producers in Mexico and, therefore, 
how this contributes to cross-plant variation in wages and the skill premium. A third extension is to model the costs to the worker of changing sectors. This will create cross-industry variation in wages and the skill premium, again allowing for more external checks of the theory.

This paper provides a model for beginning to think about technological transfer and the impact that this transfer has both upon countries that adopt it and upon the firms who invest in it. I have demonstrated that technological transfer can play an important role in determining the skill premia of countries that liberalize to one another. An interesting issue that remains is identifying the reasons that technological transfer occurs to a greater or lesser extent when certain countries open to trade and the implications that this has for inequality. 


\section{References}

(2005): “INTERNATIONAL TRADE: Mexico's Maquiladora Decline Affects U.S.- Mexico Border Communities and Trade; Recovery Depends in Part on Mexico's Actions," Discussion paper, United States General Accounting Office.

Acemoglu, D. (2002a): "Directed Technical Change," Review of Economic Studies, 69, 781810.

(2002b): “Technology and the Labor Market," Journal of Economic Literature, 40, 772.

(2009): “Patterns of Skill Premia,” Review of Economic Studies, 70, 199-230.

Acemoglu, D., G. Gancia, And F. Zilibotti (2012): “Offshoring and Directed Technological Change," Working Paper.

Alvarez, R., And R. Robertson (2004): "Exposure to Foreign Markets and Plant-Level Innovation: Evidence from Chile and Mexico," Journal of International Trade and Economic Development, 13(1), 57-87.

Amiti, M., AND L. CAMERon (2011): “Trade Liberalization and the Wage Skill Premium: Evidence from Indonesia,” CEPR Discussion Papers 8382, C.E.P.R. Discussion Papers.

Bartelsman, E. J., And W. GRAY (1996): “The NBER Manufacturing Productivity Database," Working Paper 205, National Bureau of Economic Research.

Berman, E., J. Bound, And S. MAChin (2009): "Implications of Skill-Biased Technological Change: International Evidence," The Quarterly Journal of Economics, 113(4), 1245 - 1279.

Berman, E., AND S. MACHIN (2009): "Skill-Biased Technology Transfer: Evidence Factor Biased Technological Change in Developing Countries," Leverhulme Centre for Research on Globalisation and Economic Policy (GEP), University of Nottingham.

Bernard, A. B., J. Eaton, J. B. Jensen, and S. Kortum (2003): "Plants and Productivity in International Trade," American Economic Review, 93(4), 1268-1290.

Burstein, A., J. Cravino, And J. Vogel (2013): “Importing Skill-Biased Technology," American Economic Journal: Macroeconomics, 5(2), 32-71.

Burstein, A., And J. Vogel (2010): “Globalization, Technology, and the Skill Premium: A Quantitative Analysis," (16459).

Bustos, P. (2011): “The Impact of Trade Liberalization on Skill Upgrading: Evidence from Argentina," Working Paper.

DuMARS, C. T. (1991): "Liberalization of Foreign Investment Policies in Mexico: Legal Changes Encouraging New Direct Foreign Investment," New Mexico Law Review, 21(21), 251-260.

Esquivel, G., AND J. A. RodRigueZ-Lopez (2003): “Technology, Trade, and Wage Inequality in Mexico Before and After NAFTA," Journal of Development Economics, 72. 
Esquivel, G., And A. Tornell (1995): “The Political Economy of Mexico's Entry into NAFTA," NBER Working Paper 5322.

FeEnstra, R. C. (1996): "NBER Trade Database, Disk1: U.S. Imports, 1972-1994: Data and Concordances," NBER Working Paper 5515.

(1997): "NBER Trade Database, Disk 3: U.S. Exports, 1972-1994, with State Exports and Other U.S. Data," NBER Working Paper 5990.

FEenstra, R. C., AND G. H. HANSON (1996): "Globalization, Outsourcing, and Wage Inequality," American Economic Review, 86, 240-245.

_ (1997): "Foreign Direct Investment and Relative Wages: Evident from Mexico's Maquiladoras," Journal of International Economics, 42, 371-393.

Gervais, M., N. Jaimovich, H. E. SiU, And Y. Yedid-Levi (2015): “Technological Learning And Labor Market Dynamics," International Economic Review, 56, 27-53.

Goel, M. (2012): "Does Offshoring Lift All Boats? The Role of Induced Technology Adoption and Innovation," Working Paper.

GoldBerg, P., AND N. PAVCNIK (2007): "Distributional Effects of Globalization in Developing Countries," NBER Working Paper 12885.

Grossman, G., and E. Rossi-Hansberg (2008): "Trading Tasks: A Simple Theory of Offshoring," American Economic Review, 98(5), 1978-1997.

HARrison, A., AND G. HANSON (1999): "Who Gains from Trade Reform? Some Remaining Puzzles," NBER Working paper 6915.

Kehoe, T. J. (1995): “A Review of Mexico's Trade Policy from 1982 to 1994,” The World Economy, 18, 135-151.

Kurokawa, Y. (2011): "Variety-skill Complementarity: A Simple Resolution of the Trade-Wage Inequality Anomaly," Economic Theory, 46(2), 297-325.

McGrattan, E., and E. C. Prescott (2009): "Openness, Technology Capital, and Development," Journal of Economic Theory, 144(6), 2454-2476.

PARro, F. (2013): "Capital-Skill Complementarity and the Skill Premium in a Quantitative Model of Trade," American Economic Journal: Macroeconomics, 5(2), 72-117.

Riano, A. (2009): "Trade, Technology Adoption and the Rise of the Skill Premium in Mexico," Working Paper.

RIPOLL, M. (2005): "Trade Liberalization and the Skill Premium in Developing Economies," Journal of Monetary Economics, 52(3).

Robertson, R. (2004): "Relative Prices and Wage Inequality: Evidence from Mexico," Journal of International Economics, 64, 387-409. 
Sarah Flood, Miriam King, S. R., and J. R. Warren (2015): "Integrated Public Use Microdata Series, Current Population Survey: Version 4.0. [Machine-readable database]," Technical report, University of Minnesota.

Shaiken, H., And S. Herzenberg (1987): Automation and global production: Automobile engine production in Mexico, the United States, and Canada, vol. 26. Center for US-Mexican Studies, University of California, San Diego.

Steven Ruggles, Katie GenadeK, R. G. J. G., and M. SobeK (2015): “. Integrated Public Use Microdata Series: Version 6.0 [Machine-readable database],” Technical report, University of Minnesota.

TenKate, A. (1992): “Trade Liberalization and Economic Stabilization in Mexico: Lessons of Experience," World Development, 20(5), 659-672.

Trefler, D., AND S. C. ZHU (2005): "Trade and Inequality in Developing Countries: A General Equilibrium Analysis," Journal of International Economics, 65(1), 21-48.

Tybout, J. R., And M. D. Westbrook (1995): "Trade Liberalization and Dimensions of Efficiency Change in Mexican Manufacturing Industries," Journal of International Economics, 39, 53-78.

Verhoogen, E. (2008): “Trade, Quality Upgrading, and Wage Inequality in the Mexican Manufacturing Sector," Querterly Journal of Economics, 123, 489-530. 


\section{Appendix}

\section{Additional Model Details}

\section{Households}

Households in country $k$ choose a consumption bundle $\{c\}_{i \in I}$ and bond holdings $\left(b_{k}^{\prime}\right)$ to solve the following problem:

$$
\max \sum_{t=0}^{\infty} \beta^{t} \sum_{i} \log \left(c_{k i}\right)
$$

s.t.

$$
\sum_{i} P_{k i} c_{k i}+b_{k}^{\prime}=w_{k}^{H} H_{k}+w_{k}^{L} L_{k}+(1+r) b_{k}+\sum_{i} D_{k i}
$$

In a given country, the households are identical and so in a closed economy, no bonds will be traded. Across countries, the endowment of high-skilled and low-skilled labor varies. In addition to the market clearing conditions laid out in the text, there will also be a bond market that must clear:

$$
\sum_{k} b_{k}=0
$$

